\title{
Beyond Collective Memory
}

Beyond Collective Memory analyzes how two African places became icons of collective memory for certain publics, yet remain marginal to national and continental memory discourses. Thiaroye, a Senegalese location of a colonial-era massacre, and District Six, a South African neighborhood destroyed under apartheid, have epitomized a shared "memory" of racist violence and resistant community. Analyzing diverse cultural texts surrounding both places, this book argues that the metaphor of collective memory has obscured the structural character of colonial and apartheid violence, and made it difficult to explore the complicit positions that structures of violence produce. In investigating the elisions of memory discourses, Beyond Collective Memory challenges the dominance of collective memory, and calls attention to the African pasts, metaphors, and imaginaries that exist beyond it.

Cullen Goldblatt is a scholar, writer, and translator. He holds a $\mathrm{PhD}$ in Comparative Literature from the University of California, Berkeley. His essays have been published in forums such as Interventions: International Journal of Postcolonial Studies, Research in African Literatures, and in the volume Crossings and Comparisons (LuKa - Literaturen und Kunst Afrikas). 


\section{Routledge Studies in Comparative Literature}

This series is our home for cutting-edge, upper-level scholarly studies and edited collections. Taking a comparative approach to literary studies, this series visits the relationship of literature and language alongside a variety of interdisciplinary and transnational topics. Titles are characterized by dynamic interventions into established subjects and innovative studies on emerging topics.

\section{Romantic Legacies}

Transnational and Transdisciplinary Contexts

Shun-liang Chao and John Michael Corrigan

Spanish Vampire Fiction since 1900

Blood Relations

Abigail Lee Six

\section{Holocaust Narratives}

Trauma, Memory and Identity Across Generations

Thorsten Wilhelm

Translingual Francophonie and the Limits of Translation

Ioanna Chatzidimitriou

Beyond Collective Memory

Structural Complicity and Future Freedoms in Senegalese and

South African Narratives

Cullen Goldblatt

To learn more about this series, please visit https://www.routledge.com/ literature/series/RSCOL 


\section{Beyond Collective Memory}

Structural Complicity and Future

Freedoms in Senegalese and

South African Narratives

\section{Cullen Goldblatt}

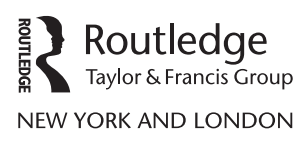


First published 2021

by Routledge

52 Vanderbilt Avenue, New York, NY 10017

and by Routledge

2 Park Square, Milton Park, Abingdon, Oxon, OX14 4RN

Routledge is an imprint of the Taylor \& Francis Group, an informa business

(C) 2021 Taylor \& Francis

The right of Cullen Goldblatt to be identified as author of this work has been asserted by him in accordance with sections 77 and 78 of the Copyright, Designs and Patents Act 1988.

All rights reserved. No part of this book may be reprinted or reproduced or utilised in any form or by any electronic, mechanical, or other means, now known or hereafter invented, including photocopying and recording, or in any information storage or retrieval system, without permission in writing from the publishers.

Trademark notice: Product or corporate names may be trademarks or registered trademarks, and are used only for identification and explanation without intent to infringe.

Library of Congress Cataloging-in-Publication Data

A catalog record for this title has been requested

ISBN: 9780367443023 (hbk)

ISBN: 9781003095538 (ebk)

Typeset in Sabon

by codeMantra 


\section{Contents}

Acknowledgments $\quad$ vi

Introduction $\quad 1$

PART I

Sites of Memory 31

1 Making Island Stones Speak 33

2 Recalling Community 59

PART 2

Places of Complicity $\quad 91$

3 Skew Intimacies 93

4 Complicit Expressions 123

PART 3

Imaginaries of Future Freedom 155

5 Holiday Time in the Twentieth Century 157

6 Archives of Future Freedom 183

$\begin{array}{ll}\text { Coda } & 199\end{array}$

Bibliography 211

Index 223 


\section{Acknowledgments}

This book has been ten years in the making. Beyond Collective Memory began life as a doctoral dissertation in comparative literature at the University of California, Berkeley. Karl Britto deserves special mention for his guidance, patience, and meticulous readership. Conversations with Debarati Sanyal about collective memory, complicity, and Ousmane Sembène's film Camp de Thiaroye have left their mark on this book, and I cannot forget Chana Kronfeld's dedicated reading_-purple pen in hand_of the very final draft of the dissertation. Exchanges with Souleymane Bachir Diagne particularly inflect Chapter 5 of this book, and it was Bachir who connected me with Alassane Ndaw, who figures prominently in that chapter. This book has also benefitted from conversations with many colleagues and friends over the years. From among them, I would like to single out the intellectual companionship of fellow members of the erstwhile Wolof Literature Working Group-Ivy Mills, Jonathon Repinecz, Fatoumata Seck, and Tobias Warner. In addition, the readership and encouragement of Kenneth Haynes, Kamil Naicker, and Shaun Viljoen have been invaluable. Finally, I would like to express special thanks to Paap Sow and Mariame Sy for assistance with translations from Wolof to English, and to Marie-Hélène Koffi-Tessio for assistance with my French to English translations. Any mistakes in this book, whether of language, interpretation, or fact, are, of course, my own.

I consulted many archives over the course of this research, among them the Archives Nationales du Sénégal, those of the Institut Fondamental de l'Afrique Noire, and the personal archives of Pape Diouf, El Haj Fall, Cheikh Faty Faye, and Maam Dawur Wade. In Cape Town, I consulted the collections of the Center for Popular Memory, the District Museum, and the National Library of South Africa, as well as many personal archives, notably those of Annie Bam, Jawayer Floris, and Lorraine and Aubrey Knight. The District Six Museum, in addition to being home to an archive, was an important subject of my research; staff members were unfailingly generous with their time and their thoughts over the course of conversations, both informal and formal. I spent many hours in the Museum's permanent exhibition, sometimes tagging along on tours led by educators, Joe Schaffers and Noor Ebrahim, and many 
more hours poring over the Museum's archival materials at my leisure, with the generous help of Chrischené Julius, Research and Collections Manager. Chris was a particularly important intellectual interlocutor, as I hope Chapter 2 makes clear.

Work on Beyond Collective Memory was supported by a number of institutions. The Department of Comparative Literature at UC Berkeley made possible the earliest stages by providing support for predissertation research; Rocca Fellowships from the Center for African Studies and a John L. Simpson Memorial Research Fellowship from the Institute of International Studies, both of UC Berkeley, made dissertation research possible. A Townsend Dissertation Fellowship was invaluable to the production of the first iteration of this work. Subsequently, two Andrew Mellon postdoctoral fellowships were crucial to the writing of this book: one fellowship at Brown University (Comparative Literature and the Cogut Center for the Humanities) and the other at Rhodes University (Literary Studies in English).

Parts of Chapter 3 are derived from two previously published articles, "Beyond the 'Memory' of Apartheid: Richard Rive and the Jewish Mock-Monarchs of Cape Town," published in the Journal of Postcolonial Writing (2017), and "Imperial Humanist Critique on the Margins of African Canons," published in Interventions: International Journal of Postcolonial Studies (2020), both copyright Taylor \& Francis. Short sections of Chapters 1 and 6 are partially drawn from the article "Toward the Space Between Words and Things: Omar Blondin Diop (Died in Detention)," which appeared in 2014 in English Language Notes, a journal presently published by Duke University Press.

It is likely that the writing of any book incurs debts that cannot be properly recognized. This book, however, truly depends on a multitude of people whom I cannot hope to repay. Over the course of more than a year of dissertation research in Cape Town and Dakar (2012-13), I was welcomed into the homes of many dozens of District Six former residents and Thiaroye residents-all of whom gave generously of themselves and their knowledge. "Mrs. Abrahams," "Margaret Pietersen," "Carol Hendricks," "Puah Gamsu," "Issa Ndoye," and "El Haj" appear over the course of Chapters 4 and 5. I am grateful to them and to many others. Although I cite from only a few transcribed exchanges, hundreds of hours of conversation and tea have made this book what is. I hope that Beyond Collective Memory does justice to the generosity, courage, and thoughtfulness of my interlocutors. 

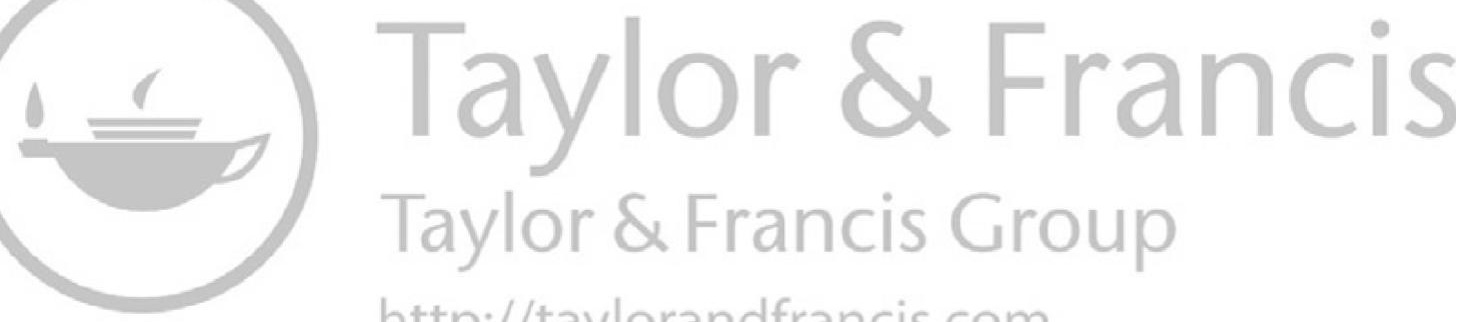

http://taylorandfrancis.com 


\section{Introduction}

This book analyzes how and why two African places became icons of memory for certain publics and yet have remained marginal to dominant discourses of national and continental memory. I trace the processes through which particular narratives of the past are presented as shared memories and investigate histories that are not collectively remembered. In exploring the elisions of memory discourses-structural violence primary among them-Beyond Collective Memory challenges the dominance of collective memory as a way of understanding the past and calls attention to archives and imaginaries that have existed beyond it.

Thiaroye, a Senegalese location of a colonial-era massacre, and District Six, a multiracial South African neighborhood destroyed under apartheid, have, for decades, epitomized "memories" of racist violence and resistant community. Narrated as "sites of memory," Thiaroye and District Six are fixed in a single dyadic narrative of the past and held at a remove from the places and histories of which they are a part. Invocations of a shared "memory" have served to elide the structural character of apartheid and colonial violence and thus deflected our attention from contemporary structural violence. Articulated as "places of complicity," however, Thiaroye and District Six emerge as heterogeneous places in the violent present which help us to think critically about the metaphors and narratives that shape our understandings of that violence and its contemporary continuities.

In the Thiaroye military camp outside of Dakar, in 1944, French colonial forces-West African colonial soldiers among them-massacred their own West African colonial soldiers. These tirailleurs sénégalais had recently returned from World War II Europe and had demanded the back pay that the military owed them. Today, basic facts about the massacre, such as the number and identities of the dead, remain unknown. The former French military camp is a Senegalese military camp, and the community of Thiaroye is a banlieue, a peripheral suburb, of Dakar, devastated by the structural adjustment policies of the 1980s and 1990s and by the neo/liberal ${ }^{1}$ economic policies that have followed. In South Africa, in 1966, the apartheid government declared Cape Town's 


\section{Introduction}

central District Six for white occupation. The District was razed and its approximately 60,000 residents, the majority of whom were classified as "Coloured," forcibly removed to the periphery of the city. Few former residents have been able to return under the terms of the post-apartheid land restitution act. Swathes of the former District remain expanses of grass and rubble, while portions are being privately developed.

Because the fundamental violence of colonial and apartheid rule was structural, it did not end with the advent of formal democracy and national independence: state forms, social hierarchies, and economic relations are largely unchanged. The postcolonial state inherited the structure of the colonial and apartheid state; hierarchies of gender, inherited social status, and, in South Africa, race, remain. Racialized capitalism continues to organize the distribution of wealth and ownership in South Africa and the position of both countries within global political and economic networks.

District Six and Thiaroye continue to be shaped by colonial- and apartheid-era forms of structural violence, such as racial classification and race-based forced relocation, which depended on positions of neither onlyperpetrator nor only-victim. Occupants of these kinds of intermediary, structurally ambivalent, positions were targets of structural violence, as well as its agents or, in a limited and relative sense, its beneficiaries. Such ambivalent positions are crucial to these two histories. French West African colonial soldiers were targets, as well as agents, of imperial violence; the South African quasi-citizens classified as "Coloured" were oppressed by a white supremacist state, even as they were privileged relative to those classified as "Native." Structurally ambivalent locations such as these produce what I call structural complicity. This is a complicity derived from the occupation of intermediary positions in state-created racialized hierarchies, rather than from the intentions or choices of the historical actors who occupied those positions. The notion of structural complicity draws attention to the structural, and therefore socially and politically complex, character of apartheid and colonial violence. Because attending to historical structural complicity means attending to the structures of violence which produced it, the idea of structural complicity provokes reflection upon the ways that colonial- and apartheid-era structural violence continues in the present, and upon the kinds of political engagement that might be commensurate with it. Thus a notion of historical complicity from which individual agency is absent foregrounds contemporary violence and raises questions of political responsibility in the present.

Recent theorizing of complicity has conceptualized it as a condition that everyone shares, the recognition of which might allow us to act more ethically. Mark Sanders, writing about the place of intellectuals in apartheid South Africa, views complicity as a precondition of all social relations, and thus as a state that precedes any taking of responsibility, including that of opposition to injustice. ${ }^{3}$ For Sanders, the recognition of 
this fundamental complicity carried a particularly intense ethical value under apartheid: to recognize our shared human "complicity" was to overcome the parochial affiliations and resultant separations that apartheid enforced and fostered. As does Sanders, Naomi Mandel, Michael Rothberg, and Debarati Sanyal, scholars whose work has theorized complicity in representations of historical violence and their reception, anchor their conceptions of complicity in the word's etymology and thus in the idea that we are "enfolded" together. ${ }^{4}$ For Sanyal, the recognition of complicity makes political engagement possible: "The recognition of complicity with structural violence, of the effects that our actions have on the fate of others, can serve as a catalyst for ethical and political action." 5 Mandel, likewise, sees complicity as both inescapable and potentially productive of political critique and ethical action. ${ }^{6}$ She argues that to deem an atrocity "unspeakable," as we often have the Nazi Holocaust, denies our relationship to that event; if we, instead, recognize and investigate our connections to, and possible implication in, historical violence, we open a space for ethical action: "Conceived not as a judgment or a charge but as a way of being, complicity evinces an ethical investment in opposition to the status quo that does not fall prey to the exculpatory lure of the unspeakable."7

My concept of structural complicity is propelled by a similar ethical impulse and intellectual curiosity. I want to understand the intertwined political and aesthetic possibilities that are opened up when representations of historical violence provoke us to recognize contemporary complicity with violence. I am especially curious, however, about the consequences of, often vast, differences of power and social position for a conception of complicity. If we understand complicity as a social condition, rather than, as in a juridical context, the result of being an accomplice to an unethical act, we might still wonder how that complicity is differently experienced and performed from varied and unequal subject positions. While everyone may be complicit in structural violence, we are complicit from within extremely varied positions. The spatial metaphor of "structural complicity," unlike that of a shared human "enfolding," demands that we begin with an acknowledgment of structural violence and the complexity of the positions and forms of participation that it demands. "Structural complicity" asks that we examine the structural quality of colonial and apartheid violence, and signals the complicity of a structurally violent present with a structurally violent past.

No metaphors of memory are necessary in order to think about how and why structural violence, and the complicities that inhered in it, exists in postcolonial and post-apartheid Africa. To the contrary, ideas of collective memory can actually obscure the enduring presence of structural violence. Moreover, contemporary memory discourses may imply that collective remembrance alone can overcome whatever remains of historical injustice: as if such "remembrance" could counter the contemporary 


\section{Introduction}

workings of racialized capitalism that make post-apartheid Cape Town resemble apartheid-era Cape Town, as if "memory" were capable of transforming a city where the political and economic relations that made possible a colonial-era massacre-and that continue to make possible the suppression of information about that massacre-endure in the present.

Yet the dominance of discourses of memory has meant that even histories of structural violence, in which structurally complicit positions are central—such as those of Thiaroye and District Six — are cast as "memories" of unified community confronted with exogenous oppression.

Myriad commemorative narratives, in a range of languages and media, have been generated around the two places, from plaques, literary texts, and oral testimonies to films and museum exhibitions. A transnational "idiom of memory," as I call it, has informed much of this varied corpus. Working through a particularly mimetic form of realism and relying on a specific kind of narrative, testimony, the idiom assumes the existence of collective memory and interpellates contemporary subjects as remembering selves. The first-person narrative of the survivor/ witness transforms the speaker, just as it does the audience who now too "remembers" past atrocity. The idiom of memory thus invites an identificatory mode of reception: we will "recall" a past of oppression and suffering that we have not ourselves experienced. A memorial imperative derives its moral force from an analogy, explicit or implicit, between Nazism and colonial or apartheid violence: we must "remember" the one, just as we must "remember" the other. Sometimes acts of remembrance and testimony are attributed to "sites of memory." The stones of Senegal's Gorée Island "speak" the suffering of the Middle Passage; the prison on Robben Island "bears witness" to the apartheid past. We, in the present, "listen" and "remember."

In the 1980s, French historian Pierre Nora's conception of lieux de mémoire, "sites of memory," ${ }^{8}$ became significant to the then-incipient field of memory studies, and today remains an important element of scholarly discourse about locations of historical violence. For Nora, memory, unlike history, is authentic, existing before and apart from an artificial modernity. Because "modern" peoples no longer live in environments of (collective) memory (milieux de mémoire), their (collective) memory is vanished and fragmented, emerging only in lieux de mémoire, thus named because they stand in lieu of, in the place of, real memory. ("Primitive" peoples still retain an authentic memory and thus have no need for lieux de mémoire.) Memory emerges organically from the collective consciousness of a people and a lieu de mémoire, a "site of memory," is any place, event, or object-a pilgrimage, a funeral, a poem, a national flag-where that memory (still) accumulates. ${ }^{9}$ While these lieux may be social inventions, Nora articulates the lieu de mémoire not as an outcome of social processes but as the outgrowth of an organic collective 
memory: a site "where memory crystallizes and secretes itself." 10 Some decolonial scholars and activists have taken up Nora's term in service of the recognition of the pasts of the formerly colonized world, including Thiaroye and the District (the greater French imperial world is found nowhere in Nora's textual instantiation of French memory). They attend to colonial violence and reject Nora's racist division between "modern," European, peoples, on the one hand, and "primitive" peoples-who still possess authentic "memory"-on the other. ${ }^{11}$

Yet weaknesses in Nora's quasi-mystical notion of memory do not vanish in Leftist scholarship that depends upon an idea of collective memory. The notion of collective memory often implies a separation between the realms of "history" and "memory" that presupposes clear divisions-such as those separating the textual and the oral, and the official and the popular-that do not reflect social reality. In fact, textual and oral narratives often coexist and overlap, and official and popular discourses about the past are mutually constitutive, or indistinguishable. Moreover, the very metaphorical extension of memory-from a single psyche to a social collective and to "sites"-obscures human agency in the making and telling of the past, and often facilitates the creation of simplistic dyadic narratives of both the past and the present. When such narratives are cast as organic accretions (of memory), they appear exempt from the analysis and critique to which we habitually subject social inventions, and they can therefore easily function to naturalize contemporary identities and relations of power.

The dominance of the idea of collective memory, and its naturalizing and identitarian character, is apparent from its presence in a type of text, the history textbook, that is generally intent on showing how the present has been historically-that is, "unnaturally"produced. According to post-apartheid South African curriculum guidelines, Grade 11 History is devoted to world history between 1850 and 1950, a period in which the development of nationalism figures prominently. A Grade 11 textbook, In Search of History, ${ }^{12}$ published in the wake of those guidelines, explains South African nationhood as part of a contingent historical development, twentiethcentury nationalism. Yet the book presents South African national identity and "memory"-termed "heritage"-as almost ahistorical. South African identity and memory are, instead, collective psychological phenomena so fundamental as to be natural. An experience of collective-national-belonging appears to be the result of the same foundational psychological operation as that which produces individual self-differentiation:

Identity is the way in which you see yourself in relation to others. It is what makes you distinctively who you are. Group identities are forged in different ways at different times in history. [. . .] An important 
type of identity in the $20^{\text {th }}$ century was national identity - the feeling of belonging to a particular nation. This could be marked by a common language, a sense of common culture or a shared history. New nations encouraged and built on a sense of national identity. ${ }^{13}$

Individual and collective experiences of selfhood are apparently analogous. Both result from what is, in effect, the same process: just as a young child learns that she is distinct from others, so too a nation comes to know itself through an equally natural progression. National identity, glossed as a "feeling of belonging to a nation," thus appears a part of the course of natural national growth. A reference to developmental delay reinforces the quasi-organic character of nation formation: "A common South African identity, which rises above differences of race or class, of urban or rural, or differing religions and languages, is only starting to develop today." 14

National identity is closely, if nebulously, connected to national memory, and both appear to exist apart from history:

Heritage (that is the way in which the past is remembered) is often used to support nationalist ideas, and also to construct identity. Sometimes there may be competing ideas about what aspects of heritage are important, about what this identity should be, and about what form the nationalism should take. ${ }^{15}$

"Memory," here encapsulated in "heritage," is employed in historical phenomena, such as identity construction and nationalism, even as it precedes and exists apart from them. While there are debates about its "aspects," the existence of such a thing as collective memory is not itself a subject of debate.

In and beyond South Africa, scholarly, pedagogical, and popular discourses connect an ostensibly shared "memory" to ethnic, racial, or national "identity" and ask that "memory" explain-and naturalize-the existence of the group. "Memory" is thus a particularly slippery, often covertly identitarian, term, existing in a tautological relationship with "identity": a people exists because its members share a "memory" and that "memory" exists because a defined people shares it. In Left-leaning scholarship and activism, such as that which informed the post-apartheid South African textbook, "memory" can function as both supplement and alternative to a limited "history": where "history" is constructed, textual, and ostensibly objective, "memory" is authentic and often oral, the imagined repository of experiences and subjectivities that are absent or denigrated within "official history." "Memory" can even suggest a redeemed future: because of "memory work," "if we remember," a different world can come into being. ${ }^{16}$ 
The idea of collective memory began to pervade popular and academic discourse in the 1970 s, ${ }^{17}$ a decade which also saw widespread interest in the lives and stories of "ordinary" people: new museums, ethnographies, memoirs, and oral histories proliferated. This rise of "memory" coincides with the beginning of our current period of Nazi Holocaust "witnessing": Annette Wieviorka traces the inception of a global "era of the witness" to the late 1970s but finds its initial roots in the Eichmann trial (1961). ${ }^{18}$ She argues that the trial and its mediatized transmission initiated a mode of representing and consuming the Holocaust in which the survivor becomes the authority on the Shoah, and contemporary listeners, viewers, and readers are invited to experience that past by identifying with the survivor. By the 1980s, the Holocaust survivorwitness would become the dominant figure through which the world "understood" the Nazi Holocaust, and oral testimony the privileged mode in which to narrate a-generally homogenized, individualized, and depoliticized-experience of persecution and survival. The primacy of "the witness," and of the mode of identificatory reception that has accompanied it, has extended beyond the Holocaust to discourses about other historical atrocities, among them colonialism, apartheid, and the Atlantic Slave Trade,${ }^{19}$ and to the marginal pasts of colonial massacre in Thiaroye and forced removal in Cape Town's District Six.

The era of the witness, and with it the rise of the idiom of memory in representations of historical violence, roughly coincided with the (re) emergence of constitutional democracies and liberal economic regimes in many parts of the world. In the late 1980s and early 1990s, with the end of the Cold War, periods of military dictatorship and authoritarian rule ended; new constitutional regimes, with formal protections for human rights, were established. However, new constitutions, strengthened and more inclusive articulations of rights, and changed occupancy of elected office did not signify the existence of lived democracy or a more egalitarian society. The economic relations that had constituted and undergirded the structural violence and radical inequalities of the previous non-democratic orders remained fundamentally unchanged, even as liberal economic policies maintained or intensified existing inequality.

In institutional and popular discourses, in museums and other sites of conscience, in the texts produced by and surrounding the Truth Commissions that were established in countries such as South Africa and Chile, the metaphor of collective memory functioned to divide a nation's just and peaceful present from its violent past. In many countries, whether or not a Truth Commission was formed, consumers of new cultural texts about the past-museum visitors, cinema and theater audiences, and readers-were invited to identify with the historical victims and "remember." ${ }^{20}$ If we never forget, the past will not repeat itself. Yet, it was not clear how our "remembrance" would prevent such repetition, 


\section{Introduction}

for Commissions did not address or remedy structural violence. They confined themselves to extralegal individual physical violations rather than also addressing the pervasive, legal, structural violence of the past. Collective victims of administrative violence were not "victims"; law-abiding technicians were not "perpetrators"; neither a changed form of state nor a redistribution of wealth were to be solutions. ${ }^{21}$

In South Africa, public steps in the transition to formal democracy began in 1990, with the release of Nelson Mandela and the unbanning of the national liberation parties, the subsequent Convention for a Democratic South Africa (CODESA) multiparty talks, and the drafting of the interim constitution (ratified in 1993). Apartheid, the regime which had begun with the election of the National Party to power in 1948, conclusively ended in 1994 with the holding of the first democratic elections. South Africa's Truth and Reconciliation Commission was established to research apartheid-era human rights violations, publically hear the testimony of victims and perpetrators, and provide restitution to victims (and amnesty to perpetrators). ${ }^{22}$ Named a "crime against humanity," apartheid would seem to be of such a scale as to entail collective, as well as individual, victims and perpetrators; of such complexity as to necessitate positions that were neither of solely victimhood nor solely perpetration. However, the Commission's public hearings and reports, as well as the discourses that surrounded it, suggested that apartheid injustice could be fully captured by many individual accounts of physical violence.

The historical scope of the Commission's investigations informed this orientation toward a dyadic rather than structural understanding of apartheid violence. The Commission's "memory" begins, as do Struggle histories, with a foundational act of physical violence, the 1960 Sharpeville Massacre, and the consequent reconfiguration of the two major nationalist movements as exiled political and military forces. The year 1960 inaugurates a history of activists and state actors, political parties, and armed resistance, rather than one of legal repression, legal structural violence, and resistance by historical actors who were not "activists."

Working with a narrow understanding of "political" and "violation," and necessarily unconcerned with the 1950s, the period in which the foundational legal structure of apartheid was created, the Commission did not address apartheid as a structure of violence. Only violations illegal under the laws of the apartheid state could be subject to investigation, and the Commission interpreted the "gross human rights violation" of its legislative mandate to mean acts of (extralegal) physical violence that emanated "from the conflicts of the past" for which a "political objective" was clear. ${ }^{23}$ In practice, "violations" were only recognized when they were committed on (or by) members of political organizations and agents of the state. The interpretation of violation (and violence) was as circumscribed as the interpretation of "political 
objective." Forms of structural violence, such as the race-based forced removal of communities, did not qualify: the implementation of state policy, forced removal was not also violence "committed in service of a political objective." 24

South Africa's Commission was a significant producer of post-apartheid memory discourse, "recalling" apartheid as principally a matter of individual rights violations, committed by perpetrators upon victims: apartheid as a "memory" of security policemen, informers, and activists. The Commission's very existence signaled that apartheid violence belonged firmly to the past. Public articulation of autobiographical narratives, especially those of "victims," reinforced this notion, performing the separation between a violent past and a shared future of peace. ${ }^{25}$ From many individual testimonies, a single account, shared by all South Africans, would emerge. Discourse produced by and surrounding the Commission articulated this process of narrative creation as memory: individual memories would come together to form one national memory. In postapartheid memory discourse, as in the Commission's hearings and final report, apartheid forms the background to a very long series of individual rights violations, rather than appearing itself as a structure of violation that targeted racialized collectives and depended upon intermediary, or "complicit," positions occupied by people who were both targets and beneficiaries of its violence. A national memory discourse refigured apartheid as a sequence of violent acts and-often black male-resistance heroes, to which and to whom "remembrance" could do justice.

Senegal, while it did not see a formal rupture akin to the end of apartheid, experienced major political changes during the period in which "the witness" came to dominate. Formally independent since 1960, Senegal saw important signs of the emergence of a genuinely democratic political order during the 1970s, with the so-called ouverture démocratique. The resignation of Senegal's first president, Léopold Sédar Senghor, at the end of 1980 after two decades in office, also constituted a significant change; he had been a member of Senegal's-first colonial, then independent-government since 1946. A second milestone occurred in 2000: after more than 50 years in power, Le parti socialiste (PS), the political party which Senghor had founded, relinquished control of the state with the election of the Liberal Party candidate Abdoulaye Wade to the presidency.

In both Senegal and South Africa, those same decades saw the adoption of liberal economic policies which prevented the actual exercise of democracy for most of the population. In Senegal, the implementation of structural adjustment policies in the 1980s and 1990s, mandated by international financial institutions, resulted in social and economic devastation; in South Africa, voluntary elite commitments to liberal economic policies meant that the racialized economic order of apartheid South Africa has remained fundamentally unchanged. 


\section{0}

In the newly independent Senegal of the 1970s, "Thiaroye" had, for Leftist intellectuals, evoked African resistance to neocolonial, as well as colonial, violence. To portray the Thiaroye Massacre was to obliquely indict the Senegalese state. In the 1980s in South Africa, for Leftist Capetonian intellectuals, District Six was an activist symbol of apartheid injustice and lost multiracial community. Following the physical destruction of the District and the forced removal of its residents, the "Hands Off District Six" campaign successfully opposed the District's apartheid redevelopment. However, by the late 1980s and mid-1990s, respectively, Thiaroye and District Six no longer functioned primarily as challenges to existing political and economic orders. Instead, they were invoked as sites of, I argue, often implicitly identitarian "memory." ${ }^{26}$ In Cape Town, informed by the activism of the late 1980s but founded in 1994, the District Six Museum became the instantiation, and primary producer, of District Six “memory.” In Senegal, Ousmane Sembène's 1987 film about the Thiaroye Massacre marked the beginning of the transnational association between the massacre and "memory." Beginning in 2004, when Abdoulaye Wade became the first Senegalese president to publically acknowledge the Thiaroye Massacre, it has been part of a state "memory" of African courage and colonial violence.

In neither place has reparative justice and meaningful democracy accompanied the rise of memory discourses. Despite the existence of a land restitution process, District Six is home to an extremely small number of former resident households. ${ }^{27}$ No restitution process exists between France and its former colonies, and no new information has been made public about the Thiaroye Massacre. Without the political will to establish or make public the identities of the dead and location(s) of their burial, there is not even a discussion about the possibility of reparations, the form they might take, and to whom they would be owed. According to official French sources, 35 tirailleurs sénégalais-members of the military force of French West African colonial subjects-were killed in Thiaroye when they "mutinied." This figure is widely disputed, as is the label of "military mutiny." As many Dakar residents, as well as scholarly and non-scholarly texts, repeat, access to the relevant French colonial and military documents would reveal the true story, in particular the true number of dead, their identities, and the location(s) of their burial.

A bare outline of events in Thiaroye is apparent from publically available sources: on November 21, 1944, the Circassia brought between 1200 and 1800 tirailleurs from Morlaix, in Normandy, to Dakar. These were the first tirailleurs to be repatriated from Europe after fighting in the World War II and most, if not all, had been German prisoners of war following the French defeat in 1940. In Thiaroye, they asked that they be paid-before leaving the camp-the back-pay and demobilization premiums that they were owed. Their demands were forceful enough that Marcel Dagnan, the general commanding the Senegal-Mauritania 
Division, came to Thiaroye with the objective of persuading the tirailleurs that they would be paid once they returned home. Some tirailleurs briefly surrounded him or held him hostage; once he promised that they would be paid in Thiaroye, they released him. Early on December 1, French colonial forces, including African soldiers, surrounded the camp and opened fire. ${ }^{28}$

The history of the cultural production of the Thiaroye Massacre is inextricable from the political history of Senegal, in which Léopold Sédar Senghor-poet, Negritude philosopher, and Senegal's first presidentoccupies a uniquely central place. ${ }^{29}$ In the 1930 s, Senghor was one of the three founding "fathers" of Negritude, which would later function as a national cultural ideology during his presidency (1960-1980). Negritude, in Senghor's articulation, conceived of African cultural specificity in relation to European cultural specificity; all cultures would converge in an ideal future "universal civilization." In its iteration as Senegalese state philosophy, Negritude not only informed the regime's politique culturelle but also functioned to explain the position of Senegal in relation to the former colonial power and served as a means through which a notion of national unity was imagined and enforced, and the repression of dissent justified.

Senghor's early poem "Tyaroye," the first literary text to respond to the Thiaroye Massacre, expresses horror at violence yet augurs an age of global peaceful French rule. The politics underpinning "Tyaroye" are those of the young Senghor, colonial politician and early Negritude poet; at the time of its publication in 1948, Senghor was one of two Senegalese representatives in the French National Assembly, working to build a global French Union, a federation with France at its head. Given the ambivalence of the poem toward French rule, it is perhaps not surprising that the Thiaroye Massacre was a taboo subject after its author became president of independent Senegal. While before independence, the massacre had been a topic of public discussion, and the Thiaroye Military cemetery a place of pilgrimage and anti-colonial protest, after 1960, a public silence surrounded the killings and the cemetery was no longer a site of public commemoration or political challenge.

The two decades of Senghor's presidency are notable for the repression of political dissent and, during a number of those years, for the absence of all but formal democracy. The 1960s saw the progressive concentration of power in Senghor's hands, and there was little independent press. In 1962, Prime Minister Mamadou Dia, along with "co-conspirators" in the government, was arrested for an attempted coup d'etat; in 1963, they were sentenced to prison. A 1963 constitutional referendum abolished the post of prime minister, and, the same year, the results of the first post-independence presidential elections proclaimed a $100 \%$ majority for Senghor. ${ }^{30}$ The December 1st march in protest of electoral fraud was met with state violence. Like the Thiaroye Massacre exactly 


\section{Introduction}

19 years earlier, this event, known as the Centenaire, became emblematic of neocolonial oppression for the Senegalese Left. ${ }^{31}$ By the end of 1966 , all opposition parties were either banned or absorbed into the ruling party; Senegal was a de facto single-party state. The state's political prisoners would come to include the young Omar Blondin Diop, who died in detention, and who appears in the first and final chapters of this book. In 1974, the regime began democratic reforms ${ }^{32}$ : a limited type of multiparty system was introduced, and 17 political prisoners were released, among them Dia, his surviving co-accuseds, and Blondin Diop's imprisoned brothers. New independent periodicals and Leftist cultural associations were created; Senghor's state, and its cultural philosophy of Negritude, became the open targets of the Senegalese Left. Culture, a primary terrain for nation-building in Senghor's Senegal, was an important area in which to contest the state.

In this changed context, the Thiaroye Massacre could publically signify an indictment of both colonial and neocolonial rule, and two new literary texts of the Thiaroye Massacre were written. Both presented challenges to Senghor's state, beginning with their allusions to Aube africaine, a choreopoem by the Guinean Fodéba Keïta ${ }^{33}$; most obviously, the protagonists of both plays shared the name of Keita's hero, and the title of Cheikh Faty Faye's play is a direct reference to that of Keïta's. Aube africaine, rather than Senghor's "Tyaroye," functioned as the imagined literary predecessor of the two postcolonial Senegalese plays. By honoring Keita's text, they also honored the anti-colonial stance of Sekou Touré's Guinea; by neglecting Senghor's "Tyaroye," they also rejected the Senghorian state's close relationship with France. Cheikh Faty Faye's play Aube de sang was published in installments in 1977 and 1978 in the new opposition periodical, And Soppi. Boubacar Boris Diop's play Thiaroye terre rouge, although written in the 1970s, was published following Senghor's departure from power, in a single volume with Diop's first novel, Le Temps de Tamango, which itself references contemporary Senegalese engagements with the Thiaroye Massacre. ${ }^{34}$ Neither Faty Faye's play nor Diop's play, as far as the playwrights are aware, has been performed in Senegal. ${ }^{35}$

The protagonist of Diop's Le Temps de Tamango writes a play about the massacre and discusses co-writing a screenplay about the massacre with his cinéaste friend. Diop himself had written a play about the Massacre-and would go on to coauthor the screenplay, Thiaroye 44, with his friend, the writer and director Ben Diogaye Bèye. In a Senegal governed by Senghor's successor, Abdou Diouf, Thiaroye 44 won the 1984 state screenplay competition; the winning screenplay would be produced by the state film production agency, the Sociéte nouvelle de promotion cinématographique (SNPC). Thiaroye 44 was under production contract with the SNPC, when its governing council, headed by Sembène, halted the production of the film that Bèye was to direct. 
The SNPC went on to produce Camp de Thiaroye, Sembène's own film, codirected with Thierno Faty Sow, about the same historical event. Rumors of French intervention surround the state body's abandonment of Thiaroye 44, the appointment of Sembène to the presidency of the SNPC board, and the SNPC's subsequent production of his own film on the same historical subject. ${ }^{36}$

In 1987, Sembène's Camp de Thiaroye ${ }^{37}$ initiated the transnational production of Thiaroye as a site of resistant memory rather than a location of contemporary political critique. Internationally by far the best-known work about the Thiaroye Massacre, and one of Sembène's best-known films, Camp de Thiaroye was the indirect fruit of the oppositional 1970s, the period when the Thiaroye Massacre had been publically named in Leftist periodicals and creatively portrayed by Faty Faye and Diop. Yet, unlike these earlier texts, Sembène's film works within the idiom of memory and refrains from indicting a neocolonial order. Rather than associate the former colonial power with the contemporary Senegalese state, as does Thiaroye terre rouge, the film identifies French colonial violence with European Nazism and asks that we "remember" both forms of racialized violence. After showing for several months in Senegal, Camp de Thiaroye was banned, an often-mentioned fact that lends support to the generally held idea that the film is an articulation of resistance. In light of the non-production and non-performance of the earlier Senegalese dramas of Thiaroye, however, the state-supported production of Sembène's film seems at least as significant as its belated banning.

Scholars have followed the lead of the film and its director in approaching Camp de Thiaroye as the articulation of a resistant memory or "counter-memory." In János Riesz's foundational essay on representations of the Thiaroye Massacre, Camp appears as the text most suited to the resistant task of memory transmission. ${ }^{39}$ Resistance is the primary concept and lens through which Sabrina Parent analyzes Camp de Thiaroye: her book chapter dedicated to the film, subtitled Art and/ as Resistance, argues that Camp enacts a resistant African recovery of the past-where Camp de Thiaroye diverges from the conventions of realism and from the historical record, it fulfills its role as [resistant] "art," as opposed to "history." 40 The notion of a resistant memory project is integral to David Murphy's framing of the film and the massacre ("Denied by the French and deliberately overlooked by the Senegalese authorities [...], the massacre at Thiaroye becomes an important symbol in the fight for the memory of colonisation.)."41

In fact, broadly speaking, scholarship about the massacre participates in memory discourse. Riesz's essay appeared in an edited collection entitled Conflits de mémoire and argues that the debates surrounding divergent narratives of the massacre demonstrate that "memories" still "conflict." ${ }^{42}$ Parent's Cultural Representations of the Thiaroye Massacre 


\section{4}

contributes to the discourse of resistant memory that has informed the reception, and sometimes the creation, of its objects of analysis. ${ }^{43}$ Historian Armelle Mabon, author of Prisonniers de guerre "indigènes ". Visages oubliés de la France occupée, has done extensive archival research on the massacre and made repeated public calls to recover its "memory." "44 Martin Mourre's Thiaroye 1944. Histoire et mémoire d'un massacre colonial (2017), the first scholarly monograph consecrated to the Thiaroye Massacre, takes its memory as one of its subjects. ${ }^{45}$

Recently, heads of state have also joined "Thiaroye" to "memory." In Senegal, President Abdoulaye Wade's 2004 acknowledgment of the massacre ushered in a new era of state commemoration. ${ }^{46}$ A national Journée du tirailleur, first celebrated in 2004, has been annually recognized with a state visit to the Thiaroye Military Cemetery, an occasion which representatives of other African states have joined. A renovation of the cemetery was completed in 2011, including the addition of a structure to house a still-projected "memorial museum." In 2012, the recently elected French President François Hollande, speaking before the Senegalese National Assembly, publically mentioned "Thiaroye," the first occasion a French president had done so. The same speech committed France to "returning" relevant, hitherto inaccessible, files about the killings.

Despite these commemorative gestures, the Thiaroye Massacre has remained a sensitive, ambiguously acknowledged, event for both states. The killings themselves are not a focus of commemoration and the Journée $d u$ tirailleur never falls on the anniversary of the Thiaroye Massacre. ${ }^{47}$ Rather than recognize French responsibility, or pronounce the word "massacre," Hollande's speeches in Senegal asked us to "remember" the sacrifice of African soldiers and the existence of a Franco-African bond. The files, shared in digital form with Senegalese President Macky Sall in 2014, have not been made public. Expressions of Senegalese and French state "memory" of the Thiaroye Massacre have since dwindled.

The Franco-African mémoire of Thiaroye recasts the imperial past as one of African sacrifice and Franco-African brotherhood. The Africanist mémoire, epitomized by Sembène's film, casts the soldiers's resistance as an act of national and continental self-assertion, and asks that "Thiaroye" prefigure national independences and decolonization. Both Franco-African and Africanist "memories" of Thiaroye foreground the courage of African soldiers and the French obligation to do justice to their "memory." Both elide the fundamentally structural, and therefore enduring, quality of colonial violence, and thereby contain the political challenges that the massacre could still present to contemporary relations of power. Both make it difficult to think about complicity, whether structural or ethical.

The dominance of discourses of collective memory has meant that even histories of violence in which structurally complicit positions are central are cast as "memories" of unified resistant community confronted with 
exogenous oppression. It requires careful crafting to shape the historical facts of the Thiaroye Massacre into such a "memory." Positions and questions of complicity are striking parts of the event and its colonial context. African French citizens, Thiaroye residents, lived a few hundred meters from where African soldiers-French colonial subjects all-were massacred. Moreover, African colonial soldiers were among the perpetrators of a massacre of other African colonial soldiers. In the episode itself, as in its larger context, the ideas of victimhood and perpetration are conceptually inadequate. Some historical actors were simultaneously beneficiaries and objects of colonial violence, or simultaneously agents and objects of that violence.

In early twentieth-century Senegal, originaires, the native-born residents of the Four Communes-Dakar, Rufisque, Saint Louis, and Goré-were formally equal to white French citizens. They were rights-possessing French citizens, even as they had no right to reject the colonial rule under which they lived. Originaires were conscripted to serve in integrated units of the colonial army, exactly as white French men were. The vast majority of French West Africans, colonial Senegalese included, were colonial subjects: they lived under a separate code of law, l'indigénat, and the men were conscripted into a segregated army, the tirailleurs sénégalais, and subject to forced non-military labor. In Thiaroye, as elsewhere on the Cap Vert peninsula, where both Dakar and Rufisque are located, originaires were often Lebu: members of a Wolof-speaking group that had a distinct, relatively privileged, relationship to the colonial administration. Thus, in Dakar and its surroundings, citizenship was generally contiguous with an ethnic, Lebu, identity.

In a sense, colonial Senegal itself, like its originaire-citizen elite, occupied a uniquely complicit position within the French imperial project in West Africa. Senegal was the base and the jardin d'essai of the French Empire in sub-Saharan Africa, and the location of the capital of L'Afrique-Occidentale française, the Federation of French West Africa (1895-1958). Senegal was where French West Africa's first colonial schools and, eventually, its only university were established, and also where, not far from Thiaroye, France created its military force composed of African colonial subjects, the tirailleurs sénégalais. Founded in 1857, the tirailleur army went on to incorporate soldiers from throughout West Africa as it conquered additional territories for France. Members of a Senegalese citizen elite administered the Empire, working throughout the Federation as teachers, civil servants, and merchants.

The colonial distinction between African citizens and subjects, including its manifestation in military service, has been minimized in postcolonial renditions of Senegalese national history. ${ }^{48}$ State narratives laud the role of Africans in liberating France but do not dwell on their role in maintaining French empire; textbooks present colonial military participation but do not reflect on the dual regime of citizen and subject, and 


\section{6}

the consequently differentiated military experience. ${ }^{49}$ Just as the colonial army's killing of tirailleurs in Thiaroye is acknowledged, so too is the historical existence of tirailleurs and originaires. These elements of the past are not denied or omitted. Rather, they are neglected: mentioned in passing, and then disavowed or simply abandoned, their possible implications left unexamined. Structurally complicit positions, and the questions of ethical complicity they can provoke, remain unexplored.

The paradigmatic Senegalese national subject is a black heteronormative member of a free nation. In an imaginary informed by a traditional Wolof social order, as well as by masculinist nationalism, he is also of noble and free (non-slave) descent-géer and gor." Three hierarchical binary pairs compose the basic organization of a social order that remains operative in postcolonial imaginaries and lived realities. The binary opposition of gor (free) and jaam (slave) forms the hierarchy's foundation; gor is further divided into the superior géer (high-caste) group and the inferior ñeeño (low-caste) group-members of the latter are defined by their occupations. Neeño is also composed of two hierarchical categories: the relatively higher status artisan castes ${ }^{50}$ and the inferior sab-lekk, whose work is to sing or speak for the géer. The géwél-griot-who today largely stands in for the broader grouping of sab-lekk, is singer, drummer, (oral) historian, and entertainer. Griots are permitted a verbal and physical expressiveness that is not publically permitted to géer, who adhere to a code of reticence and modesty understood to be noble. The griot, and his work of proxy communication, is essential yet degraded; despite his political role, he cannot be a political actor in his own right. ${ }^{51}$ Only people of free and high-caste descent are imagined to be endowed with full dignity and thus to be full social members and political actors. Góor-jigéenliterally "man-woman" - is a third gender category that is today identified with "male homosexual." Like the géwél, the góor-jigéen is permitted an expressiveness that the (dichotomously gendered) socially superior géer is not. As historically the géwél has been, today the góor-jigéen is located outside the imagined borders of the social and political body. ${ }^{52}$

The primary protagonists of dominant national memory in South Africa are black Struggle heroes-whether Robben Island prisoners, Umkhonto weSizwe (MK) fighters, or figures of African cultural resistance such as Steve Biko. Narratives of historical struggle highlight the contributions of the primary national liberation movement, today the ruling African National Congress (ANC), in the fight against apartheid. ${ }^{53}$ Robben Island, where, most famously, Nelson Mandela was held as a political prisoner, is remembered as a site of national resistance and unity, and black ANC leaders, in particular, are celebrated. Leaders of other movements, such as Robert Sobukwe, founder of the Pan Africanist Congress

* I spell Wolof words according to the orthography used in Jean-Léopold Diouf's Dictionnaire wolof-français et français-wolof (Paris: Karthala, 2003). 
(PAC), are subsumed into triumphalist, ANC-centered, imaginaries of resistance. ${ }^{54}$ The roles of other movements-such as the non-racialist Cape Town-based Non-European Unity Movement-go largely neglected.

South African non-racialism rejected the idea of race itself, thus refusing "the very epistemological basis of apartheid" 55 : even to recognize the white supremacist invention of race was to perpetuate it and thus to impede the arrival of the post-apartheid, necessarily non-racial, future. As an assertion of the invented and imposed character of race, non-racialism was an element of multiple anti-apartheid political traditions, from African nationalist movements to faith-based coalitions. Primarily, however, the term specifically refers to the Cape Town-based, Marxist and Marxist-influenced, politics in which the Non-European Unity Movement played a prominent part. ${ }^{56}$ Founded in 1943, the Unity Movement once inserted South African political struggles onto a world stage. Although it never became a national force in South Africa, the Unity Movement remained a powerful influence on Cape Town-based political groups, such as the Teacher's League of South Africa, and it is an important reference in the history that the District Six Museum tells, both in its permanent exhibition and in narratives of its institutional origins. ${ }^{57}$

In the 1990s, an Africanist notion of South Africa as a specifically black African nation competed with multi-racialist and non-racialist conceptions of South Africa's past and present. ${ }^{58}$ Today, the multiracialist "rainbow nation" nationalism of the 1990s, the era of Mandela's presidency, has been largely superseded by an Africanist conception of South Africa, to which Cape Town and District Six, like the social and political heterogeneity they connote, are marginal. ${ }^{59}$ This marginal location is evident even in a text that is intent on producing an objective and inclusive conception of the nation and its past: In Search of History, the post-apartheid high school history textbook we looked at earlier. Cape Town's District Six makes a very fleeting appearance in the textbook's discussion of the apartheid past, alongside Sophiatown-perhaps South Africa's most famous site of apartheid forced removal-as an object of apartheid legislation, in the section "People are Separated." 60 the District is entirely absent from the subsequent presentation of resistance; Sophiatown alone goes on to appear as a primary example of anti-apartheid resistance. A photograph, captioned "Graffiti in Sophiatown," visually introduces the unit on anti-apartheid resistance, despite the fact that the image does not portray resistance in any direct sense (men sit on a curb, seemingly playing a game, below large dark letters spread across a white wall: WE WONT MOVE). Reproduced again three pages later, the same photograph becomes a "source" for a learning activity about resistance ${ }^{61}$; the caption, on this second occasion, suggests that the image depicts collective resistance to forced removal: "In 1953 and 1954, the people of Sophiatown put up a spirited resistance to their removal, after Sophiatown was declared a white group area. Many refused to move until they were forcibly relocated by police [. . .]." 62 


\section{8}

Both Sophiatown and District Six might be legitimately depicted as nationally significant sites of anti-apartheid resistance and destroyed cosmopolitan community. Community protests followed the declaration of the District; Sophiatown was home to a heterogeneous array of people, as Don Mattera attests. ${ }^{63}$ Sophiatown, however, historically home to a large African population and located in Johannesburg, is imagined as black and therefore as a resistant and national site. District Six, imagined as Coloured and perennially described as "colourful" and "cosmopolitan," is not cast as resistant or African and does not possess an analogously national imagined status.

The textbook, like the dominant national imaginary, portrays Sophiatown as the site of black resistance to forced removal; District Six makes a substantive appearance only in its institutional instantiation as "memory." There are no images of the historical District Six, but there are three photographs of the District Six Museum, which is cast as a place of "heritage" - a word that was glossed many chapters earlier as "memory"-for a democratic South Africa because of its inclusive representation of the cosmopolitan District. Readers learn about curatorial practices and about what representations of national heritage should be and do, but learn little about Cape Town or District Six.

Since its foundation, Cape Town has been a port city and a place of visible racial and cultural mixing, as well as of enslavement and segregation. For much of its existence, the Cape Colony was a slave society and Cape Town a hub of the Indian Ocean Slave Trade: people forcibly brought from the Indian Ocean world, including East Africa, and some West Africans, were enslaved during periods of both Dutch and British rule. ${ }^{64}$ Indigenous Khoi and San people were killed and dispossessed, the survivors and their descendants compelled to work alongside enslaved counterparts. On the final abolition of slavery in $1838,{ }^{65}$ the majority of Cape Town was composed of the descendants of this heterogeneous black population. The city's unique cultural landscape and demographics are informed by this colonial history: almost half of the city's residents are identified as "Coloured" ${ }^{66}$; Islam has a significant presence, one as old as Cape Town itself; "Cape Cuisine" is distinctive, and Afrikaans is understood to be a particularly local and Coloured (or black) language-Afrikaaps ${ }^{67}$ of the Cape, die Kaap.

A racial classification in colonial and apartheid orders, "Coloured" 68 was a usefully capacious category for white supremacist domination, and one much contested by those it purported to name. Under apartheid, "Coloured" encompassed those who were classified as neither "white" nor "Native," and privileged "Coloured" people relative to those named "Native." Early apartheid legislation defined a "coloured person" as whoever is "not native or white"; such a person was thus of mixed racial heritage and intermediary political status. ${ }^{69}$ In the 1970 s and 1980 s, with the prominence of Black Consciousness (BC) thought and the 
resurgence of popular resistance of both non-racialist and BC orientations, most anti-apartheid activists rejected the category of "Coloured" as a racist invention and an element of a "divide and rule" strategy. Among some Leftist intellectuals today, a continued aversion to "Coloured" hearkens back to that embrace of shared blackness and therefore shared liberation. "Coloured," however, remains a way that many people identify themselves and others-unsurprisingly, given that the end of apartheid did not signify a change in where and how most people lived: spatial and social segregation and racialized economic inequality remain largely unchanged.

A structurally complicit category, "Colouredness" has been associated with complicity and sexual and racial impurity, in part because of associations between Colouredness, historical enslavement, and historical sexual violence. ${ }^{70}$ Cape Town, like the Colouredness with which it is joined, remains uniquely imaginatively linked with not only racial but also gendered and sexual, mixing, passing and non-conformity, a place closely connected with the (Coloured) moffie, the figure of male homosexuality and femininity. For locals, if not within locally produced memory discourse, District Six exemplifies Cape Town in this regard: former residents recall well-known queens, night spots famous for their drag performances, and the moffie netball team. Historically home to brothels and cabarets, prominent queens, and visible homosexuals, District Six was also where men from the respectable city went for their pleasures.

While queerness is marginal to dominant articulations of the District's memory discourse, two notable cultural texts of the early 2000s have focused on queer life in District Six: Rozena Maart's novel Rosa's District Six and Jack Lewis's documentary film A Normal Daughter: The Life and Times of Kewpie of District Six, both appearing in 2004, represent the District as a lost place of generally accepted homosexuality and the open transgression of middle-class gender norms. A recent exhibition held at the District Six Museum (September 2018-January 2019), and cocurated with the queer archive GALA, ${ }^{71}$ Kewpie: Daughter of District Six, centered on the same historical personage as Lewis's film. ${ }^{72}$

Urban settlement of the area just east of Cape Town's center and adjacent to the harbor-what would become known, in 1867, as District Six - began in the nineteenth century, as recently freed former slaves joined Capetonians of many classes and complexions. By 1900, however, the District was predominantly working-class and included a majority whom the Cape Colony government variously categorized as "Coloured," "Malay," and "Mixed and Other." There was also a large number of Jews who had fled Eastern Europe, and people of many other origins, including Africans from the Eastern Cape, Indians, Chinese, and Australians. ${ }^{73}$

The District was thus well established before the creation of a polity called South Africa: it was only in 1910 that the new Union of South 


\section{Introduction}

Africa, a British Dominion, joined the territories and interests of the two white elites, the British winners and the Afrikaner losers of the South African War (1899-1902) - at the expense of the black majority. The ANC, then the South African Native National Congress (SANNC), was founded shortly thereafter to protect the rights of Africans. In 1948, an overwhelmingly white electorate brought an Afrikaner ethnonationalist party, to power. The National Party had campaigned with the promises of intensified segregation and white domination, apartheid and baaskop (literally, "separateness" and "master rule"). Almost immediately, key pieces of apartheid legislation formalized and intensified existing legal and de facto forms of segregation. The Population Registration Act (1950) divided people into three races- "native," "coloured," and "white"; the Group Areas Act (1950, amended in 1956) mandated residential segregation based on those racial classifications; the Prohibition of Mixed Marriages Act (1949) made marriages between white people and people of other races illegal (the Act was shortly followed by the Immorality Act (1950), which prohibited sexual relations between white people and people of other races).

The 1950s saw national anti-apartheid resistance, culminating in the 1955 Congress of the People and the signing of the Freedom Charter, still today a foundational national document. Following the Sharpeville Massacre in 1960, the two national liberation movements, the ANC and the PAC, were banned and went into exile. The 1960s were a decade of increasing political repression and of the implementation of apartheid legislation. Resistance would not flourish again within South Africa until 1976, when a student uprising in Soweto quickly spread to urban areas around the country and initiated more than a decade of popular revolt.

As the regime began implementing its master plan of racial segregation in Cape Town, District Six was one of many central areas proclaimed for exclusive white residence under the Group Areas Act. While the District had been a first place of residence for migrants and immigrants of many colors and geographic origins in the late nineteenth and early twentieth centuries, by the early post-World War II period, residents were primarily black; the majority would be classified as "Coloured." Most of the, collectively more economically mobile, white inhabitants-including a substantial Jewish population-had, by then, moved from the District voluntarily; the last African residents were forcibly removed in the 1950s. Thus, at the inception of apartheid, District Six, was workingclass, multiracial, and primarily Coloured; it was also far larger-in area, population, and cultural presence-than a single "neighborhood."

The physical destruction of the District-its buildings and street grid-and the removal of its residents proceeded incrementally, beginning in the late 1960s. By the early 1980s, the entire population had been forcibly relocated; the few structures left standing include the three 
mosques and four churches that remain today. Black residents were forcibly moved to separate, racially defined, areas on the margins of the city. Because of the District's central location and size, and the long period over which it was demolished, its destruction was very visible, as are, still today, the consequences of that destruction.

In the 1980 s, as the regime became increasingly repressive in response to widespread resistance, it began implementing token reforms, including the hollow (re)enfranchisement of South Africans classified as "Coloured" and "Asian." District Six was the proposed site of another such token reform: the future District would be one of South Africa's new model non-racial areas, its redevelopment led by BPSA (the South African affiliate of British Petroleum, which, unlike many multinationals, never divested from apartheid South Africa). It was therefore just as the District's destruction was completed that it became the site of public political contestation. Local activists, former residents among them, fought the BP-led initiative and advocated for a future democratic redevelopment of the District, to be led, instead, by former residents who would return to the land with the end of the unjust apartheid regime. The activist project of fighting an apartheid redevelopment of the land was bound up in the activist project of commemorating the District. ${ }^{74}$ For overlapping contingents of activists, scholars, and cultural producers, District Six became a highly visible, and much researched and photographed, symbol of apartheid injustice. The District was also a focus of social historians based at the University of Cape Town, and the first research site of the Western Cape Oral History Project, subsequently the Centre for Popular Memory.

Cultural and activist work coalesced in the 1988 Hands Off District Six Conference. Cape Town's District Six Museum, the cultural institution dedicated to District Six and its memory, traces its roots to this conference. A landmark collection of essays dedicated to District Six history and culture: The Struggle for District Six: Past and Present, a "Project of the Hands Off District Committee," edited by two members of the Committee (both of whom were to become Museum trustees), was the conference's direct fruit. The District Six-born author, Richard Rive, whose work is considered in this book, contributed to the conference and to the volume. ${ }^{75}$ The Hands Off District Six Campaign and Conference were successful; the planned "non-racial" apartheid neighborhood did not come to be, nor was the District redeveloped as a white area, at least in part because white people were generally unwilling to move there. In the 1980s, then, the District remained largely devoid of new buildings, but for the construction of the large new campus of an all-white technical college in the center of the District: the Technikontoday the Cape Peninsula University of Technology (CPUT), the largest institution of tertiary education in the Western Cape Province. The same forces that prompted the token reforms of the 1980s-widespread 


\section{Introduction}

popular resistance, economic sanctions against South Africa, and increasing international condemnation of apartheid-led, in conjunction with the end of the Cold War, to the negotiated dismantling of apartheid, during secret talks in the 1980s and in public negotiations in the early 1990s.

The production of the District as "memory" begins with the activist movement to commemorate the District and fight for its democratic redevelopment, and with the concomitant cultural production of the District, in works such as Richard Rive's novel 'Buckingham Palace', District Six (1986) and Taliep Petersen and David Kramer's District Six: The Musical (1987). With the end of apartheid, memory discourse intensified: since the first democratic elections in 1994, and the founding of the Museum the same year, there has been a plethora of cultural and scholarly production surrounding District Six, including texts of fiction and scholarship, collections of photographs, museum exhibitions, documentary films, and memoirs authored by former residents (as well as more musicals about the District from Petersen and Kramer, and from Kramer alone, after Petersen's death in 2006).

In multiple genres and media, District Six is articulated as a "memory" of apartheid injustice and vanished community; some texts, including the Museum Foundation's own publications, position the Museum as a primary site of District Six "memory." 76 To "remember" the District is to "recall community" 77 and to consider the community of the destroyed District as a metonym of what post-apartheid South Africa is or should become. This "memory" is overtly-but not wholly, I will argue-one of a non-racial cosmopolitan community. In this dominant collective "memory," while apartheid created and legislated racial distinction, in the District-a place of vibrant social interaction and working-class solidarity-race was unimportant to the formation of resistant social bonds.

In Beyond Collective Memory, I argue that, rather than a new pantheon of lieux de mémoire, or a more inclusive collective memory that risks naturalizing often identitarian narratives of the past and present, we need new metaphors, ones that help us to recognize historical complexity and to express our necessarily varied relationships to the past. In moments, expressions, and passages that work outside of memory's idiom, we glimpse places of complicity, where we encounter the structural violence and complexity of the past and the present.

This book also reflects, and invites reflection, on how our understandings of historical violence shape what we conceive of as an archive for the African present. It asks that we reconsider what might constitute an African literature of decolonization or protest, and that we think anew about the kinds of interpretation that would be adequate to the complexities and complicities of past and present violence. What metaphors, 
aside from collective memory, and what African literary texts, beyond the borders of current canons, might we draw on in order to narrate the past and its relation to the present? Beyond the "memory" of apartheid and colonial rule, what histories might we encounter and what future freedoms might we imagine?

\section{Notes}

1 With "neo/liberal” I follow what I take to be James Ferguson's suggestion regarding structural adjustment policies in Africa, that much of what is referred to as "neoliberal" is actually liberal: "Neoliberalism here was (in these terms) not very 'neo' at all. It was, in fact, largely a matter of old-style laissez-faire liberalism in the service of imperial capital" ("The Uses of Neoliberalism," Antipode 41, no. S1 (2009), 173 (doi: 10.1111/j.1467-8330.2009.00721.x)).

2 Apartheid legislation, and definitions that predated apartheid, constructed "Coloured people" as the product of racial mixing. In reference to South Africa, I employ "African," "Coloured," "Indian," and "white"-the racial categories of the post-apartheid state, and use "black" to refer to all "nonwhite" people.

3 In Sanders's understanding, complicity is a condition that precedes any stance, whether of collaboration or opposition: "When opposition does not free one from complicity, but depends on it as its condition of possibility, responsibility is sharpened." Mark Sanders, Complicities: The Intellectual and Apartheid (Durham, NC: Duke University Press, 2002), 10.

4 See Michael Rothberg, Multidirectional Memory: Remembering the Holocaust in the Age of Decolonization (Stanford, CA: Stanford University Press, 2009) and The Implicated Subject: Beyond Victims and Perpetrators (Stanford, CA: Stanford University Press, 2019). Works by Debarati Sanyal and Naomi Mandel are cited below.

5 Debarati Sanyal, Memory and Complicity: Migrations of Holocaust Remembrance (New York: Fordham University Press, 2015), 13.

6 Naomi Mandel, Against the Unspeakable: Complicity, the Holocaust, and Slavery in America (Charlottesville: University of Virginia Press, 2006), 23.

7 Mandel, Against the Unspeakable, 218.

8 The "site of memory" is the framing concept of the three-volume history of France that Pierre Nora edited: Les Lieux de mémoire (Paris: Gallimard, 1984-92). Translated into English as Realms of Memory, the volumes appeared in English in the 1990s. Nora's introduction to the collection, first published in translation in a 1989 special issue of Representations, was important to the formation of Anglophone memory studies scholarship.

9 "Between Memory and History: Les Lieux de Mémoire," in "Memory and Counter-Memory," eds. Natalie Zemon Davis and Randolph Starn, special issue, Representations no. 26 (Spring 1989), 23.

10 Ibid, 7.

11 A very partial list of such scholars would include Brett Ashley Kaplan, Naomi Mandel, Debarati Sanyal, Max Silverman, and Michael Rothberg.

12 Jean Bottaro, Pippa Visser, and Nigel Worden, In Search of History: Grade 11, Learner's Book (Cape Town: Oxford University Press Southern Africa, 2006).

13 Bottaro, Visser, and Worden, In Search of History, 171.

14 Ibid. 


\section{Introduction}

15 Ibid, 182.

16 Critiques of contemporary deployments of collective memory include Kerwin Lee Klein, "On the Emergence of Memory in Historical Discourse," "Grounds for Remembering," special issue, Representations 69 (2000): 127-50; Walter Benn Michaels, "'You Who Never Was There': Slavery and the New Historicism, Deconstruction and the Holocaust," Narrative 4, no.1 (1996): 1-16; and David Berliner, "The Abuses of Memory: Reflections on the Memory Boom in Anthropology," Anthropology Quarterly 78, no.1 (2005): 197-211.

17 Klein, "On the Emergence of Memory in Historical Discourse," 127.

18 Annette Wieviorka, The Era of the Witness, trans. Jared Stark (Ithaca, NY: Cornell University Press, 2006).

19 See, inter alia, Rothberg, Multidirectional Memory (2009); Sanyal, Memory and Complicity (2015).

20 The "International Coalition of Sites of Conscience" website provides many examples (https://www.sitesofconscience.org/en/home/). Founded in 1999, the Coalition is a "global network of historic sites, museums and memory initiatives that connect past struggles to today's movements for human rights. We turn memory into action." Among its members are the Maison des esclaves on Gorée, and the District Six, Sophiatown, and Apartheid Museums in South Africa. Latin American site-museums include those established following military dictatorships; in Europe, there are member institutions in Terezin and Srebrenica.

21 This is, broadly, the critique first put forth by Mahmood Mamdani of South Africa's Truth and Reconciliation Commission, and pursued by others, such as Colin Bundy and Richard Wilson.

22 The Commission's legislative mandate is set out in the Promotion of $\mathrm{Na}$ tional Unity and Reconciliation Act (No. 34 of 1995). The nation-building intention is also explicit in the final article of the Interim Constitution of 1993, which committed the government to granting amnesty to perpetrators (nothing is said of victims or reparations).

23 Republic of South Africa. Promotion of National Unity and Reconciliation Act (No. 34 of 1995), 1.

24 Mahmood Mamdani's critique $(2001,2002)$ emphasizes that the Commission failed to address structural violence and that this failure was due to the manner in which the Commission interpreted the key terms of its legislative mandate (2002, 36-42). Heidi Grunebaum (2011) analyzes the consequent understanding of the political realm as narrow and divorced from everyday life.

25 Scholarship on the Commission and the understandings of the past that it produced includes Graeme Simpson and Deborah Posel, eds, Commissioning the Past: Understanding South Africa's Truth and Reconciliation Commission (Johannesburg: Wits University Press, 2002); Sarah Nuttall and Carli Coetzee, eds, Negotiating the Past: The Making of Memory in South Africa (Cape Town: Oxford University Press, 1998); and Heidi Grunebaum, Memorializing the Past: Everyday Life in South Africa after the Truth and Reconciliation Commission (New Brunswick, NJ: Transaction Publishers, 2011).

26 In the case of District Six, this shift was part of a broader national tendency: an array of post-apartheid nation-building discourses and projects, the Commission significant among them, employed collective memory. Historians and non-state projects of "public history" and "heritage" also invoked and discussed [collective] "memory." Vivian Bickford-Smith, Sean Field, and Clive Glaser describe the new centrality of "memory" to oral history work 
in South Africa during the 1990s ("The Western Cape Oral History Project: The 1990s," African Studies 60, no. 1 (2001): 5-23). Collective memory remains a foundational and ubiquitous concept in more recent works of South African scholarship about the past, among them Gabeba Baderoon, Regarding Muslims: From Slavery to Post-apartheid (Johannesburg: Wits University Press, 2014) and Pumla Dineo Gqola, What Is Slavery to Me?: Postcolonial/Slave Memory in Post-apartheid South Africa (Johannesburg: Wits University Press, 2010).

27 At the time of writing, in early 2020, 139 restitution houses have been completed in District Six.

28 See Myron Echenberg, “Tragedy at Thiaroye: The Senegalese Soldiers' Uprising of 1944," in African Labor History, eds. Peter Gutkind, Robin Cohen, and Jean Copans (Beverley Hills: Sage Publications, 1978), 109128; Mbaye Gueye, "Le 1ère décembre 1944, à Thiaroye ou le massacre de tirailleurs sénégalais anciens prisonniers de guerre," Revue sénégalaise d'Histoire 1 (1995): 3-23; Martin Mourre, "La Répression de Thiaroye. Décrire les différents degrés de la violence coloniale," Les Temps Modernes 2 (2017): 87-110; and Martin Mourre, Thiaroye 1944. Histoire et mémoire d'un massacre colonial (Rennes: Presses universitaires de Rennes, 2017). On the contradictory details offered in different French military accounts, including regarding the number of tirailleurs aboard the Circassia, and the number of tirailleurs injured and killed, see Mourre, Thiaroye $1944,44-72$.

29 Relevant sources on Senegal's political history include Momar-Coumba Diop and Mamadou Diouf, eds, Le Sénégal sous Abdou Diouf: Etat et société (Paris: Karthala, 1990) and Donal Cruise O'Brien, Momar-Coumba Diop, and Mamadou Diouf, eds, La Construction de l'Etat au Sénégal (Paris: Karthala, 2002).

30 Senghor received $100 \%$ of valid votes and $99.47 \%$ of all votes cast. In the national legislative elections held the same day, the ruling party received $94.2 \%$ of the vote and thus won all National Assembly seats. "Election in Senegal” African Elections Database. http://africanelections.tripod.com/ sn.html.

31 See inter alia, the interview with Madia Diop in Visages publics du Sénégal, eds. Falilou Ndiaye, Manfred Prinz, and Alioune Tine (Paris: Harmattan, 1990), 192-205 and Donal Cruise-O'Brien, "Political Opposition in Senegal: 1960-67,” Government and Opposition 2, no. 4 (1967): 562 (doi: 10.1111/j.1477-7053.1967.tb01185.x). I discuss a contemporary Leftist Wolof poem that references both this march and Thiaroye in "Toward the Space between Words and Things: Omar Blondin Diop (Died in Detention)," "Cartographies of Dissent," special issue, English Language Notes 52, no. 2 (Fall/Winter 2014): 174-6.

32 By Senghor's departure at the end of 1980, three political parties had been recognized, each representing one of the four recognized political currents (the ruling party occupied the "Socialist current").

33 The play was first published in 1949 in the journal Réveil. See Sabrina Parent, Cultural Representations of Massacre: Reinterpretations of the Mutiny of Senegal (New York: Palgrave Macmillan, 2014), 49. I reference the text in the more widely available volume, Aube africaine (Paris: P. Seghers, 1965).

34 Boubacar Boris Diop, Le Temps de Tamango, suivi de Thiaroye terre rouge (Paris: L'Harmattan, 1981). Cheikh Faty Faye's master's thesis in History, which treats the Massacre, is referenced in Diop's novel. 


\section{Introduction}

35 Interview with Cheikh Faty Faye, May 23, 2013; email communication from Boubacar Boris Diop, July 19, 2017. Martin Mourre states that the play was staged in Senegal, but he offers no details (Thiaroye 1944, 134).

36 This account is based on my conversations with Ben Diogaye Bèye in April 2013. For a published sketch of events, which alludes to French influence on the production of Sembène's film and the "non-production" of Bèye and Diop's film, see Mahama Johnson Traoré, "Cinema and Freedoms: Reflections of a Senegalese Film-Maker," in African Experiences of Cinema, eds. Imruh Bakari and Mbye B. Cham, trans. Paul Willemen (London: British Film Institute, 1996), 67-9. Traoré, a director and poet, was Director General of the SNPC when Thiaroye 44 was in production, and, according to Bèye, communicated the decision to halt (at first, seemingly temporarily) production.

37 Ousmane Sembène and Thierno F. Sow, Camp de Thiaroye (Senegal and Tunisia: SNPC and SATPEC, 1987).

38 For example, in Memory and Complicity, Sanyal refers to the film as a "colonial countermemory" (132).

39 János Riesz, "Thiaroye 44: un événement historique et ses représentations littéraires" in Conflits de mémoire, ed Véronique Bonnet (Paris: Karthala, 2004), 315.

40 Parent, Cultural Representations, 103.

41 David Murphy, Sembène: Imagining Alternatives in Film and Fiction, (Trenton, NJ: Africa World Press, 2001) 162. Both "memory" and "resistance" also figure in the title of the relevant chapter: "Camp de Thiaroye: Dis-membering Empire, Re-membering Resistance: The Memory of Colonisation.” Murphy goes on to cite Sembène, whose words are similarly reliant on conjoined notions of resistance and memory:

[.. .] thanks to the film, these men are no longer dead. The French killed them but their cemetery still exists in Dakar. [. . . B Before this film, these were simply anonymous graves, but all that has changed now. Now, when we have friends visiting, we say, "Let's go to the cemetery in Thiaroye," and they come with us to see the cemetery. [. . .] we are keeping alive the memory of their history.

In Sembène: Imagining Alternatives, 162-3

42 Riesz, “Thiaroye 44,” 311.

43 Parent's introduction makes evident this approach:

All these documents representing Thiaroye participate in forming the 'collective memory' of West African people. [. . .] the concept of 'collective memory' is useful in pointing out that artists have transformed testimonies of survivors, dying because of old age, into memories of a people, for whom Thiaroye assumes a role of social cohesion.

In Cultural Representations, 7

44 See, for example, Armelle Mabon, "Le Massacre de Thiaroye, une synthèse," Histoire coloniale et postcoloniale, March 9, 2015. https://histoirecoloniale.net/le-massacre-de-Thiaroye-une.html.

45 Mourre has also brought about, with Roger Little, the publication of Bèye and Diop's never-produced screenplay, Thiaroye 44: Ben Diogaye Bèye and Boubacar Boris Diop, Thiaroye 44. Scénario inédit (Paris: L'Harmattan, 2018).

46 As president, Abdoulaye Wade also wrote, with M’baye Gana Kébé, Une Fresque pour Thiaroye: théâtre (Dakar: Éditions Maguilen, 2008). In this same "era of the tirailleur," Faty Faye's play, originally published in installments in 1977 and 1978, was brought out by L'Harmattan. 
47 La Journée du tirailleur was first celebrated on August 23, 2004, the sixtieth anniversary of the liberation of Toulon (in which tirailleur participation was significant). The date has varied between years.

48 One indication of this is that Wade's state translated the Journée du tirailleur as the "Day of the Colonial Soldier"; and for post-independence generations broadly, tirailleur does mean simply "African (black) colonial soldier."

49 See, for example, Iba Der Thiam, Seydou Sow, and Gora Kane, Histoire $d u$ Sénégal et de l'Afrique (Dakar: Nouvelles Editions africaines, 2009).

50 Among these artisan castes are blacksmiths, jewelers, weavers, and wood workers.

51 Abdoulaye Bara Diop, La Société wolof: les systèmes d'inégalité et de domination (Paris: Karthala, 1981). See also Mamadou Diouf, "Essai sur l'histoire du Saalum," Revue sénégalaise d'Histoire, no. 1 (1981), 25-37 and Ivy Mills, "Sutura: Gendered Honor, Social Death, and the Politics of Exposure in Senegalese Literature and Popular Culture" (Ph.D. diss, University of California, Berkeley, 2011). These categories of person constitute endogamous social groups; scholars disagree about whether the term "caste" is fitting.

52 Ivy Mills makes this argument in the third chapter of her dissertation (“Sutura," 118-66).

53 For a critique of triumphalist post-apartheid national narratives, see Jacob Dlamini, Native Nostalgia (Johannesburg: Jacana, 2009) and the discussion in Chapter 3 of this book.

54 See, for example, Martin Legassick and Gary Minkley's analysis of the imagery on the then-newly opened Robben Island (Museum) pier: "Current Trends the Production of History," Alternation 5, no. 1 (1998): 98-129.

55 Grant Farred, Midfielder's Moment: Coloured Literature and Culture in Contemporary South Africa. (Boulder, CO: Westview Press, 2000), 14.

56 On non-racialism, see, inter alia, Farred (cited above); Zimitri Erasmus, "Rearranging the Furniture of History: Nonracialism and Anticolonial Praxis," Critical Philosophy of Race 5, no. 2 (2017): 198-222; Julie Frederikse, The Unbreakable Thread: Nonracialism in South Africa (Cape Town: Ravan Press, 1990); Jon Soske, “The Impossible Concept: Settler Liberalism, Pan-Africanism, and the Language of Non-racialism," African Historical Review 47, no. 2 (2015): 1-36; and Shaun Viljoen, "Richard Rive: Non-racialism in a Life of Writing and of Sport," South African Journal for Research in Sport, Physical Education, and Recreation 33, no. 2 (2011): 127-41 and Shaun Viljoen, Richard Rive: A Partial Life (Johannesburg: Wits University Press, 2013).

57 For example, the activities of the Unity Movement and associated groupings are noted on the "Timeline" of the Museum's permanent exhibition, Digging Deeper. Non-racialism and the Unity Movement are persistent referents in accounts of the Museum's political commitments and activist beginnings. See, inter alia, Crain Soudien, "District Six and Its Uses in the Discussion about Non-racialism," in Coloured by History, Shaped by Place: New Perspectives on Coloured Identities in Cape Town, ed. Zimitri Erasmus, 114-30, (Cape Town: Kwela Books, 2001) and Crain Soudien, "From Protest to Protest" in The Struggle for District Six: Past and Present, eds. Shamil Jeppie and Crain Soudien, 143-81 (Cape Town: Buchu Books, 1990).

58 In Rethinking the South African Crisis: Nationalism, Populism, Hegemony (Scottsville: University of KwaZulu-Natal Press, 2012), Gillian Hart identifies three processes of post-apartheid "re-nationalization" that, she says, 


\section{Introduction}

have emerged with neoliberal processes of denationalization led by corporate capital (including, but not limited to, structural adjustment policies and the privatization of formerly national economic enterprises): "rainbowism"; draconian anti-immigration policies and sentiments ("Fortress South Africa"); and the discourse surrounding the National Democratic Revolution (NDR), the model adopted by the ANC and the SACP in 1962 that would understand the present as the national (capitalist) stage in a two-part revolution: the socialist revolution is still to come (6-9). Although these processes coexist, there has been a movement away from the liberal, multiculturalist "rainbowism" of the 1990s and toward more exclusivist modes of Africanist nationalism.

59 Baderoon discusses the tendency to cast the Cape, and its history of slavery and Islam, as marginal or exceptional to the nation and its past, and the attendant risk that those historically regarded as "Coloured" are not included within a national narrative (Regarding Muslims, 14-6).

60 Bottaro, Visser, and Worden, In Search of History, 207. The section begins thus: "Two of the most infamous examples were the destruction of District Six in Cape Town (in terms of the Group Areas Act) and of Sophiatown in Johannesburg (in terms of the Native Resettlement Act of 1954).”

61 "Resistance to apartheid in the 1950s was marked by mass action involving ordinary people on a large scale. Study sources A to $\mathrm{H}$ and explain what you learn about the mood and nature of the resistance of this period from them" (Ibid, 224).

62 Ibid, 222.

63 Don Mattera, Memory Is the Weapon (Johannesburg: African Perspectives Publishing, 2009). First published 1987 by Ravan (Johannesburg).

64 The colonized Cape was first Dutch (1652-1795), briefly British (17951802), briefly Dutch again, before British rule was reestablished in 1806, enduring, in varied forms, until South Africa exited the Commonwealth in 1961.

65 Abolition in 1834 was followed by a mandatory four-year period of unpaid "apprenticeship."

66 In 2012 , the city's population was " $42.2 \%$ Coloured" and " $28.6 \%$ black African"; the remainder is variously categorized as "white," "Indian/Asian," and "other." Numerically dominant languages are Afrikaans (34.9\%), IsiXhosa (29.2\%), and English (27.8\%). Statistics South Africa http://www. statssa.gov.za/?page_id=1021\&id=city-of-cape-town-municipality.

67 A reference to the Afrikaans particular to the Coloured Cape (Kaap); the term was made famous by Dylan Valley's eponymous documentary film: Afrikaaps (Amsterdam: Plexus Films/The Glasshouse, 2010).

68 Analyses of Colouredness include Zimitri Erasmus, ed, Coloured by History, Shaped by Place: New Perspectives on Coloured identities in Cape Town (Cape Town: Kwela Books, 2001) and Mohamed Adhikari, ed, Not White Enough, Not Black Enough: Racial Identity in the South African Coloured Community (Athens: Ohio University Press, 2005). On the local history and "memory" of slavery in the Cape, see, inter alia, Robert C. H. Shell, Children of Bondage: A Social History of the Slave Society at the Cape of Good Hope, 1652-1838 (Hanover, NH: Wesleyan University Press, 1994); Kerry Ward and Nigel Worden, "Commemorating, Suppressing, and Invoking Cape Slavery," in Negotiating the Past, eds. Nuttall and Coetzee, 201-17; and Baderoon, Regarding Muslims.

69 Union of South Africa, Population Registration Act (No. 30 of 1950). A 1959 extension of the Act established a fourth racial category, "Indian." 
70 Relevant analyses include Zimitri Erasmus, "Introduction: Reimagining Coloured Identities in Post-apartheid South Africa," in Coloured by History, ed. Erasmus, 3-28; Zoë Wicomb, "Shame and Identity: The Case of the Coloured in South Africa," in Writing South Africa: Literature, Apartheid and Democracy, 1970-1995, eds. Derek Attridge and Rosemary Jolly, 91-107 (Cambridge: Cambridge University Press, 1998), and Baderoon, Regarding Muslims (see, in particular, the discussion of the specificity of Colouredness in Chapter 4, "Sexual Geographies of the Cape").

71 Established in 1997 as the Gay and Lesbian Archive, GALA has subsequently expanded its work beyond the archive and beyond the borders of "gay" and "lesbian" identities. In 2007, the organization renamed itself "Gay and Lesbian Memory in Action," while retaining the acronym, GALA. In 2020, the name is again a subject of reflection (https://gala.co.za/about/history); the website currently describes GALA as "a centre for Lesbian, Gay, Bisexual, Transgender, Intersex and Queer (LGBTIQ) culture and education in South Africa" (https://gala.co.za).

72 The exhibition, cocurated with Johannesburg's Market Photo Workshop, was shown at the Workshop from May to July 2019.

73 No scholarly monograph is dedicated solely to the history of District Six. However, several of the essays in Jeppie and Soudien's The Struggle for District Six: Past and Present specifically address the District's past, such as Vivian Bickford-Smith's “The Origins and Early History of District Six to 1910" (35-43) and Deborah M. Hart's "Political Manipulation of Urban Space: The Razing of District Six, Cape Town" (117-42).

74 See Crain Soudien, "District Six: From Protest to Protest."

75 Rive's essay focuses on literary treatments of District Six: "District Six: Fact and Fiction," in The Struggle for District Six, 110-16.

76 Examples include Annie Coombes, "District Six: The Archeology of Memory," in History after Apartheid: Visual Culture and Public Memory in a Democratic South Africa (Durham, NC: Duke University Press, 2003), 116-48; Ciraj Rassool, "Memory and the Politics of History in the District Six Museum," in Desire Lines: Space, Memory and Identity in the Postapartheid City, eds. Noëleen Murray, Nick Shepherd, and Martin Hall, 113-27 (New York: Routledge, 2007); “An Archeology of Memory,” Mail \& Guardian Online, March 2, 1995. http://mg.co.za/article/1995-02-03-anarchaeology-of-memory. Published shortly after the Museum opened (and cited by Rassool, above), this last declares that the Museum "witnesses," "creates an archeology of memory," and "stages a recovery of the past." Museum publications include Ciraj Rassool and Sandra Prosalendis, eds, Recalling Community in Cape Town: Creating and Curating the District Six Museum (Cape Town: District Six Museum, 2001); and Bonita Bennett, Chrischené Julius, and Crain Soudien, eds, City, Site, Museum: Reviewing Memory Practices at the District Six Museum (Cape Town: District Six Museum, 2008).

77 Recalling Community in Cape Town, cited above, is the title of an essay collection published by the District Museum Foundation about Museum practice. The phrase is a touchstone in Chapter 2 of this book.

1 As I will describe, the 1966 guidebook to Gorée includes a photograph portraying President Auriol on the staircase of the Maison des esclaves. Given the history of the house today known as the Maison des esclaves, it would seem that this was a different "Slave House."

2 See the UNESCO World Heritage Site "Description” texts for Gorée and Robben Island, respectively: http://whc.unesco.org/en/list/26 and http:// whc.unesco.org/en/list/916. 
3 "May this monument and the museum strengthen our resolve that never again shall this land see the oppression of one by another; nor the suppression of any community's heritage." "Address by Nelson Mandela on Heritage Day,” Cape Town, September 24, 1997, http://www.mandela.gov.za/ mandela_speeches/1997/970924_heritage.htm

4 UNESCO, Convention for the Safeguarding of the Intangible Cultural Heritage, Article Two - Definitions. https://ich.unesco.org/en/convention.

5 The preamble to South Africa's national heritage legislation (1999) provides another example, defining "heritage" in terms of its supportive relationship to national identity: "[Our heritage] helps us to define our cultural identity and therefore lies at the heart of our spiritual well-being and has the power to build our nation."

6 "To be directly or tangibly associated with events or living traditions, with ideas, or with beliefs, with artistic and literary works of outstanding universal significance." All UNESCO world heritage sites must be "of outstanding universal value" and must meet at least one of ten criteria. See http://whc. unesco.org/en/criteria/.

7 UNESCO, The Critieria for Selection, https:/whc.unesco.org/en/criteria/.

8 "Synthetic Report of the Meeting on 'Authenticity and Integrity in an African Context', Great Zimbabwe National Monument, Zimbabwe, 26-29 May 2000," in "Report of the Bureau of the World Heritage Committee', 24th session, 26 June-1 July 2000, Paris," as cited in Harriet Deacon, "Intangible Heritage in Conservation Management Planning: The Case of Robben Island," International Journal of Heritage Studies 10, no. 3 (2004), 311.

9 UNESCO, Robben Island: Brief Synthesis, http://whc.unesco.org/en/list/916.

10 When former President Nelson Mandela opened the Robben Island $\mathrm{Mu}-$ seum on Heritage Day in 1997, the conclusion of his speech made explicit the identifications-between political imprisonment on Robben Island and the (resistant) South African nation, and between the island prison and the apartheid regime-which the UNESCO text implies: "Let us recommit ourselves to the ideals in our Constitution, ideals which were shaped in the struggles here on Robben Island and in the greater prison that was Apartheid South Africa." "Address by Nelson Mandela on Heritage Day," September 24, 1997, Cape Town.

11 Robben Island Museum, “Ex Prisoner Stories,” http://www.robben-island. org.za/stories.

12 Specialized tours, the museum website informs, can take up to eight hours and include visits to multiple sites on the Island (as does the "virtual tour" on the website).

$13 \mathrm{http}: / / \mathrm{ww}$ w.robben-island.org.za/stories

14 See Aaron Bady's thoughtful analysis of the omissions that Mandela's iconic status demands:

We can remember that he [Mandela] refused anything less than unconditional release from prison, for example, only if we also forget that he eventually chose to negotiate his release, and broke with many of his comrades in doing so; we can remember Mandela as the central authorizing figure of the struggle only if we also forget the many other parties and movements that contested that centrality [. . . ].

In “Robben Island University,” Transitions 116 (2014), 114

15 UNESCO, Island of Gorée: Criterion (vi), http://whc.unesco.org/en/list/26.

16 For a summation of scholarly positions in this debate, see Djibril Samb, ed. Gorée et l'esclavage : actes du séminaire sur "Gorée dans la traite atlantique : mythes et réalités” (Gorée, 7-8 avril, 1997) (Dakar: IFAN-Cheikh Anta Diop, 1997). The debate has also taken place periodically on the academic listserve, now an online "commons," HNET West Africa. 
17 UNESCO, Island of Gorée: Description, http://whc.unesco.org/en/list/26.

18 Hamady Bocoum and Bernard Toulier, "La Fabrication du patrimoine: l'exemple de Gorée (Sénégal)," In Situ 20 (2013), 5-6. http://insitu.revues. org/10303.

19 Pierrette Hertzberger-Fofana, “Joseph Ndiaye (1922-2009), la voix de la maison des esclaves de Gorée s'est éteinte,” Grioo.com, October 2, 2009. http://mobile.grioo.com/article.php?id=16316.

20 "Tyaroye" in Chants d'ombre suivi de Hosties noires (Paris: Éditions du Seuil, 1956), 143-4. The poem was originally published in Hosties noires (Paris: Éditions du Seuil, 1948).

21 Joseph Boubacar Ndiaye, Histoire et traite des noirs à Gorée : l'esclavage, ses origines et ses répercussions en Afrique, avec des citations de l'auteur (Dakar: Maison des esclaves, 1986), 29.

22 Aimé Césaire, Discours sur le colonialisme (Paris: Présence africaine, 1955), 7.

23 Aimé Césaire, 1979, Discourse on Colonialism, trans. Joan Pinkham (New York: Monthly Review Press, 2000), 31.

24 See Lilyan Kesteloot, Comprendre les poèmes de Léopold Sédar Senghor (Issy Les Molineaux: Classiques africains, 1986), 40; and Sabrina Parent, Cultural Representations of Massacre: Reinterpretations of the Mutiny of Senegal (New York: Palgrave Macmillan, 2014), 39.

25 Césaire, Discours, 23.

26 Bocoum and Toulier, "La Fabrication du patrimoine," 5-6.

27 Raymond Mauny, "En marge du centenaire de l'abolition de l'esclavage, l'île de Gorée," Paris-Dakar, April 22, 1948, 19, cited in Boucoum and Toulier, "La Fabrication du patrimoine," 6.

28 Boucoum and Toulier, "La Fabrication du patrimoine," 4.

29 Number 31 of the many "Quotations from the Author" reads, "A profound emotion, a symbol of the dignity of each being, of a dignity of each being [sic], Of a dignity denied from Gorée to Auschwitz" (Joseph Ndiaye, The Slave Trade at Gorée-Island and Its History, Slavery: Its origins and Consequences in Africa (with Quotations from the Author), trans. Momar Khary Diagne (Dakar: Maison des esclaves, (1989?)), pages unnumbered.

30 Léopold Sédar Senghor, "Préface : De l'île de Gorée à la nation sénégalaise" in Jean Delcourt, La Turbulente Histoire de Gorée (Dakar: Clairafrique, 1982), xi.

31 I leave "Nègre" untranslated since, as a Negritude concept, the word has no English translation (it is neither "Negro," the literal translation, nor "Black" (Noir)).

32 http://www.ina.fr/video/CAF89027584/festival-des-arts-negres-a-dakarvideo.html.

For a discussion of Malraux's speech and role within the festival, see Éloi Ficquet and Lorraine Gallimardet, “'On ne peut nier longtemps l'art nègre,"” Gradhiva [online] 10 (2009): 134-55. doi: 10.4000/gradhiva.1560.

33 For more about the festival and its significance, see David Murphy, ed., The First World Festival of Negro Arts: Context and Legacies (Liverpool: Liverpool University Press, 2016).

34 The Marxist parti africain de l'indépendance (PAI) was founded in 1957, in the Senegalese town of Thiès, and was outlawed by the newly independent Senegalese state in 1960.

35 Abdoulaye Bathily, interviewed by Falilou Ndiaye, Manfred Prinz, and Alioune Tine, in Visages publics du Sénégal : 10 personnalités politiques parlent, eds. Falilou Ndiaye, Manfred Prinz, and Alioune Tine (Paris: Harmattan, 1990), 118.

36 Charles Babacar Seck, Gorée: Guide Touristique (Dakar: SAFER, 1966).

37 Mark Hinchman, writing of Gorée in the eighteenth century, explains that "African women owned most of the houses, and the word signare, deriving from the Portuguese word senhora, became a signifier of class for wealthy African and mixed-race women." (Portrait of an Island: The Architecture 
and Material Culture of Gorée, Senegal, 1758-1837 (Lincoln: University of Nebraska Press, 2015), 7).

38 In Senghor's poem "Joal," for example, the signare embodies the poet's memory of Africa and the métissage that would become central to Senghor's Negritude.

39 "Admirez la peau veloutée de la jeune métisse : elle va de la teinte crème jusqu'au café au lait foncé” (Seck, Gorée. Guide Touristique, 26).

40 Seck, Gorée. Guide Touristique, 25.

41 Ibid, 34-5.

42 Ibid, 28.

43 Abdoulaye Camara and Joseph-Roger de Benoist, Gorée : Guide de l'île et du Musée historique (Dakar: IFAN-Cheikh Anta Diop, 1993), 29.

44 Ostensibly erected for defensive purposes, the Fort saw military action only once, when, in 1940, it warded off the Free French Forces' attempt to land in Vichy-ruled French West Africa.

45 See Ibrahima Thiaw, "L'Espace entre les mots et les choses: mémoire historique et culture matérielle à Gorée" in Espace, culture matérielle et identités en Sénégambie, ed. Ibrahima Thiaw (Dakar: CODESRIA, 2010), 33-4.

46 Thiaw, "L'Espace entre les mots et les choses," 34.

47 In Wolof, jaamu neg and jaamu sayoor; in the French-language scholarship which followed the Wolof terms, l'esclave de case, and l'esclave de traite.

48 Thiaw, "L'Espace entre les mots et les choses," 19-20.

49 "'L'espace entre les mots et les choses' est un site où le discours historique est confronté à la réalité matérielle pour évaluer leurs potentialités et limites respectives" (Ibid, 18). Thiaw cites Martin Hall, "Subaltern Voices? Finding the Spaces between Things and Words," in Historical Archaeology: Back from the Edge, eds. Pedro Paulo, A. Funari, Martin Hall, and Sîan Jones (London and New York: Routledge, 1999), 193-203.

50 Thiaw, "L'Espace entre les mots et les choses," 24.

51 République du Sénégal, Ministère de l'Information et des Relations avec les Assemblées, Livre blanc sur le suicide d'Oumar [sic] Blondin Diop (Dakar: Ministère de l'Information et des Relations avec les Assemblées, 1973).

52 Lettre de Dakar (Éditions Champ Libre: Paris, 1978), 47. The anonymous authors name the date as May 14, 1973 and state that protests continued all over the country for two weeks.

53 The memorial celebration in 2013 consisted of two events: an afternoon-long homage held at the Université Cheikh Anta Diop on May 10 and the unveiling of the commemorative plaque on Gorée on May 11. For an account of these events, see Cullen Goldblatt, "Toward the Space between Words and Things: Omar Blondin Diop (Died in Detention)," English Language Notes 52, no. 2 (Fall/Winter 2014): 163-83.

54 There has been a proliferation of Senegalese and other Francophone African media attention to O.B. Diop surrounding the May 2013 commemorations and more recent anniversaries of his death.

1 For example, the tirailleurs are forced to exchange the uniforms that the US military had provided them (prior to their arrival in Dakar) for the racially marked uniform of the tirailleur. In a culminating act of injustice, the military insists that the tirailleurs' metropolitan French francs be exchanged for French African francs at half the actual rate of exchange.

2 Another, historically related, meaning of ceddo is "a non-Muslim pagan." The Wolof word is a borrowing from Pulaar. On the connotations of ceddo, and the word's association for Sembène with refusal, see also Tobias Warner, 
The Tongue-Tied Imagination: Decolonizing Literary Modernity in Senegal (New York: Fordham University Press, 2019), 148-9.

3 Mamadou Diouf, Le Kajoor au XIXe siècle: pouvoir ceddo et conquête coloniale (Paris: Karthala, 1991).

4 Ceddo [pseudonym, likely Ousmane Sembène], “Moom Sa Réew,” in "Independaas," special issue, Kaddu (1972), first (unnumbered) page.

5 Umar Tall waged a war of Jihad in response to colonial conquest; at its peak, the Umarian empire covered a large part of contemporary Mali.

6 Ceddo, “Moom Sa Réew," Kaddu, first (unnumbered) page.

7 Boroom Jamono Yi, “Xewoonu Mee” Kaddu no. 20, 9 [publication year unknown, likely 1974 or 1975 ].

8 Mamadou Diouf emphasizes the film's intended function as a critique of the postcolonial present ("Histoire et actualités dans CEDDO d'Ousmane Sembène et HYENES de Djibril Diop Mambéty," in Littérature et cinéma en Afrique francophone : Ousmane Sembène et Assia Djebar, ed. Sada Niang (Paris: L'Harmattan, 1996), 15-34).

9 All three documentary images are stills from Alain Resnais's documentary film, Night and Fog (1955). The first two photographs were taken in Mauthausen; the third in Buchenwald. See Debarati Sanyal, Memory and Complicity: Migrations of Holocaust Remembrance (New York: Fordham University Press, 2015), 137-9.

10 The Brazzaville Conference (1944) was convened by the French National Liberation Committee to determine the future of the colonies within the post-war Empire. In the opening speech, de Gaulle declared that it was the role of France to help the people of all its territories to become capable of participating in the management of their own affairs. Although autonomous self-governance was never mentioned, some saw the Conference as a sign of progress. Raymond seems to evoke "Brazzaville" in this spirit of decolonial republican optimism.

11 Kenneth Harrow and Debarati Sanyal have discussed this point. See Kenneth Harrow, "Camp de Thiaroye: Who's That Hiding in Those Tanks and How Come We Can't See Their Faces?” IRIS 18 (1995): 147-52 and Debarati Sanyal, Memory and Complicity, 141-2.

12 "Deed of Trust, District Six Museum Foundation.” April 11, 1994. District Six Museum Archives, Cape Town.

13 Ciraj Rassool clearly articulates this position: "One of the most important aspects of the mission of the District Six Museum is to question race at every turn and to assert a politics of nonracialism and anti-racism in every facet of its work." Non-racialism is glossed, in passing, as "a position which questions the validity of race and racial categories" (introduction to Rassool and Prosalendis, Recalling Community, x).

14 See Chrischené Julius, “'Digging Deeper than the Eye Approves’: Oral Histories and Their Use in the Digging Deeper Exhibition of the District Six Museum," Kronos 34, no. 1 (2008): 106-38 and "Oral History in the Exhibitionary Strategy of the District Six Museum, Cape Town,” Master's Thesis, University of the Western Cape, 2007.

15 Ibid.

16 The language of archeology has also permeated how others have written about Digging Deeper. Examples include Annie Coombes, "District Six: The Archeology of Memory," in History after Apartheid: Visual Culture and Public Memory in a Democratic South Africa (Durham, NC: Duke University Press, 2003), 116-48; Ciraj Rassool, "Memory and the Politics of History in the District Six Museum," in Desire Lines: Space, Memory and 
Identity in the Post-Apartheid City, eds. Noëleen Murray, Nick Shepherd, and Martin Hall (New York: Routledge, 2007), 113-27; "An Archeology of Memory," Mail \& Guardian Online, March 2, 1995. http://mg.co.za/ article/1995-02-03-an-archaeology-of-memory.

17 The first floor also contains "Nomvuyo's room," a re-creation of the childhood bedroom of a former resident (and one of the ways that Digging Deeper highlights the historical African presence).

18 "Bioscope" was the name of an early motion picture projector; the word became synonymous with "cinema" in Britain's Central and Southern African territories. See James Burns, "The African Bioscope - Movie House Culture in British Colonial Africa," Afrique \& histoire 1, no. 5 (2006): 65-80.

19 The other permanent exhibit in the Hall is "the Writer's Floor": the floor tiles bear handwritten literary excerpts referencing the District.

20 Two new swathes of calico are available for contemporary ink jottings: one intended for ex-residents and the other for other visitors. Julius, "Digging Deeper than the Eye Approves," 109.

21 See Julius, “'Digging Deeper than the Eye Approves,"” 118-9 and 131-2.

22 Ibid, 118.

23 I draw on Julius's description of material detail in the visual presentation of (originally oral) text, see in particular "'Digging Deeper than the Eye Approves," 118-9.

24 Bill Nasson, "She Preferred Living in a Cave with Harry the Snake-Catcher: Popular Leisure and Class Relations in District Six, c. 1920s-1950s," in History Matters: Selected Writings (Cape Town: Penguin Books, 2016), 168. Nasson was a trustee of the District Six Museum Foundation and cofounder of the Western Cape Oral History Project (subsequently the Centre of Popular Memory). Nasson's essay, first published in the year of Richard Rive's death, is dedicated to his memory.

25 [Former] Horstley Street was chosen to be the site of a future Memorial Park in 1993, before the Museum had opened its doors.

26 They are Molly Herman (née Bailen) and Morris Gawronsky.

27 See Jon Soske, "The Impossible Concept: Settler Liberalism, Pan-Africanism, and the Language of Non-racialism," African Historical Review 47, no. 2 (2015): 1-36.

28 The Jews of District Six exhibition was held from November 2012 until March 2013. My citations of exhibition text reference the exhibition's catalogue which reproduces the text and images of the exhibition panels: Millie Pimstone, Milton Shain (convener) and Adrienne Folb, The Jews of District 6: Another Time, Another Place (Cape Town: Kaplan Centre for Jewish Studies, 2012).

29 "New Exhibition: The Jews of District Six: Another Time, Another Place." Press Release. South African Jewish Museum, Cape Town. [October 2012, document not dated.]

30 Pimstone, Shane, and Folb, The Jews of District Six, 10.

31 Ibid, 75.

32 A rare mention of race implies that Jews shared a uniform racialized class status: the children of the Jews of District Six "were fast becoming an integrated part of the privileged white community" (The Jews of District Six, 68). Jewish poverty appears as an initial immigrant condition that preceded inevitable affluence; photographs of working life portray prosperous merchants and their businesses.

33 "Acknowledgments," displayed at the end of the exhibition and on the final page of the catalogue, recognizes research institutions and organizations 
from which materials were sourced (including the District Six Museum), and names some of the former residents whose words are quoted, but does not attribute any particular text or image to any particular source.

34 "Perhaps one of my earliest recollections-and indeed a very clear one-is that of a sunny Sunday morning in 1922 when the children of Cape Town Jewry ... paraded in a procession through the streets of the city to mark the ratification of the Balfour Declaration [. . . " (attributed to Solly Rechtman, The Jews of District Six, 36).

35 Ibid.

36 A partial list of such anti-apartheid organizing would include the NonEuropean Unity Movement, small groups of the 1960s and 1970s such as the National Committee for Liberation/African Resistance League (NCL/ARM, founded in 1960), and Cape Town's United Democratic Front (founded in 1983).

37 Pimstone, Shaine, and Folb, The Jews of District Six, 37.

38 Jack and Ray were politically prominent as individuals and as a couple, and coauthored Colour and Class in South Africa: 1850-1950.

39 Pimstone, Shaine, and Folb, The Jews of District Six, 74.

$40 \mathrm{Or}$, as when, in documentary mode, the film tells us the precise time of the massacre.

41 See Armelle Mabon, Prisonniers de guerre "indigènes " and Echenberg, "'Morts Pour la France;' The African Soldier in France during the Second World War," The Journal of African History 26, no. 4 (1985), 363-80.

42 For example, it is improbable that, in a city founded on the racist displacement of people, the 1901 forced relocation of African Horstley Street residents would be the first forced removal.

43 Rassool, Recalling Community, xi.

1 "Riva" was first published in the South African literary journal Staffrider in March 1979; the slightly revised version referenced here appeared in Rive's 1983 short story collection Advance, Retreat (60-72).

2 While published in 1981, immediately following Senghor's departure, Thiaroye terre rouge was written in the late 1970 s.

3 The exceptions are analyses of the cultural representations and "memory" of the Thiaroye Massacre, such as Riesz's essay “Thiaroye 44," Parent's volume Cultural Representations of Massacre, and Mourre's history, Thiaroye 1944.

4 This history deserves an attention that it has not yet publically received, as do the intertextual relationships between Thiaroye terre rouge, the now-published Thiaroye 44, and Camp de Thiaroye. Here, however, my interest is focused on an analysis of the play, in light of our understanding of Sembène's film as a work of "memory."

5 Boubacar Boris Diop, Thiaroye terre rouge, in Le Temps de Tamango, suivi de Thiaroye terre rouge (Paris: L'Harmattan, 1981), 147-203.

6 Ibid, 148.

7 Ibid, 151-2.

8 Ibid, 152.

9 Ibid, 153.

10 Ibid.

11 Ibid, 154.

12 Ibid, 157.

13 Ibid, 158-9.

14 Ibid, 160.

15 Ibid.

16 Ibid, 162.

17 Ibid.

18 Ibid, 164.

19 Ibid, 172.

20 Ibid. 
21 Ibid, 165.

22 Ibid, 170.

23 Ibid, 165.

24 Ibid.

25 "Bachir est tout à fait ahuri: il écarquille les yeux tout en reculant. Brusquement, il fait demi-tour et s'enfuit." (Bachir is completely stunned; he recoils, wide-eyed. Abruptly, he turns on his heel and flees.) (Ibid, 185)

26 Ibid, 186.

27 Ibid, 195.

28 Ibid, 196-7.

29 Ibid, 181.

30 Ibid, 183.

31 Ibid, 185.

32 Ibid, 197.

33 It may also be one of Senghor's most misunderstood statements. Souleymane Bachir Diagne describes this much-cited sentence as part of Senghor's earliest theoretical formulation of Negritude, found in his 1939 essay, "Ce que l'homme noir apporte," and argues that Senghor's conception of Negritude transformed as it matured. (Interview by Nadia Yala Kisukidi, "Senghor et la question qui se pose toujours," ThéoRèmes 4 (Nov. 2013). http://theoremes.revues.org/430.) Rather than only an assertion of particularity (let alone intellectual inferiority), Diagne argues that, for Senghor, Negritude was one facet of an already single humanity and universal culture: African specificity exists only as a term in a relation whose synthesis is a universal human civilization. Negritude, then, is a coming-into-being that cannot be fixed in time, let alone attached to a specific racial group (see Diagne, Léopold Sédar Senghor: l'art africain comme philosophie (Paris: Riveneuve Editions, 2007) and Diagne, "In Praise of the Post-Racial: Negritude Beyond Negritude," Third Text 24, no. 2 (2010): 241-8.)

34 Diop, Thiaroye terre rouge, 192.

35 Ibid, 193.

36 Ibid.

37 Ibid.

38 Ibid, 200-1.

39 Ibid, 201.

40 Cabora Bassa, a major dam project in what would become Mozambique, was a repeated target of Frelimo freedom fighters.

41 Diop, Thiaroye terre rouge, 202.

42 On the latter occasion, in the play's first reference to the audience, Moctar gestures toward viewers and declares that they will do nothing for "us"; he then chooses to remain with the uprising: "Je reste avec vous" (I am staying with you) (Ibid, 189).

43 Ibid, 202.

44 Ibid.

45 Ibid, 203.

46 Ibid.

47 These physical actions are expressed concisely in the stage directions: "Il se lève, étonné, regarde partout." (Surprised, he rises, and looks all around.) (202); and "ll s'écroule-Chant." (He collapses-Chant.) (203).

48 I have made this argument elsewhere. Parts of this chapter's treatment of Rive's apartheid-era work and post-apartheid status are drawn from two articles: "Beyond the 'Memory' of Apartheid: Richard Rive and the Jewish Mock-Monarchs of Cape Town," Journal of Postcolonial Writing 53, no. 4 (2017), 454-68 (doi: 10.1080/17449855.2017.1307259) and "Imperial Humanist Critique on the Margins of African Canons," Interventions: International Journal of Postcolonial Studies (2020, forthcoming) (doi: 10.1080/1369801X.2020.1718533). 
49 As I noted in the introduction, Rive participated in the Hands Off District Six conference in 1988, and contributed to the result collection of essays, The Struggle for District Six, published in 1990, the year following his death.

50 Fazeela Haffejee, English Senior Curriculum Planner (Western Cape Education Department), in discussion with the author, November 13, 2012, Cape Town.

51 Shaun Viljoen, Richard Rive: A Partial Biography (Johannesburg: Wits University Press, 2013), 183.

52 The novel itself is insistently non-racialist-racial labels are never applied to District residents and race-based solidarity is not thematized, let alone celebrated.

53 On the novel's first page, the unnamed narrator quietly inserts himself into the world of the primary narrative, recalling that his childhood home was in the Palace; his family (like the author's own family) occupied number 207. Interestingly, in the primary narrative, there are no characters who might correspond to the members of his childhood household. We follow only the occupants of numbers 201, 203, 205, and 209.

54 Richard Rive, 'Buckingham Palace', District Six (Cape Town: David 1996), 10-1. First published in 1986 by David Philip (Cape Town).

55 Ibid, 29.

56 Ibid, 28.

57 Ibid, 8 .

58 Ibid, 9.

59 Ibid.

60 Ibid, 2.

61 Ibid, 3.

62 Ibid, 107.

63 Vivian Bickford-Smith briefly discusses this historical nationalist sentiment, citing Rive's novel as proof of its mid-century presence: "Writing about Englishness: South Africa's Forgotten Nationalism," in Empire and After: Englishness in Postcolonial Perspective, eds. Graham McPhee and Prem Poddar (New York and Oxford: Berghahn Books, 2007), 62-3.

64 Ibid, 149.

65 Ibid, 150.

66 Ibid, 152.

67 Ibid, 197-8.

68 Ibid, 198.

69 Non-European Unity Movement, "Declaration to the Nations of the World," paragraph eight, Cape Town, July, 1945.

70 Rive, 'Buckingham, Palace,' 175-6.

71 Ibid, 179.

72 "Riva" has, however, been claimed as work of "lesbian and gay" South African literature. It was included in the first South African anthology of lesbian and gay writing: Matthew Krouse, ed, assisted by Kim Berman, Invisible Ghetto: Lesbian and Gay Writing from South Africa (Johannesburg: Congress of South African Writers, 1993) and subject to a queer reading (Shaun Viljoen, "Richard Rive: Non-racialism in a Life of Writing and of Sport," South African Journal for Research in Sport, Physical Education, and Recreation 33 (2013), 169-72).

73 Richard Rive, "Riva," in Advance, Retreat, 60-1.

74 Ibid, 63.

75 Ibid.

76 Ibid.

77 Ibid, 63-4. 
78 Ibid, 65.

79 Ibid, 66.

80 Ibid.

81 Ibid, 67.

82 Ibid.

83 Ibid.

84 Ibid, 68.

85 Ibid.

86 Brenna Munro (South Africa and the Dream of Love to Come: Queer Sexuality and the Struggle for Freedom (Minneapolis: University of Minnesota Press, 2012)) and Shaun Viljoen (Richard Rive, 2013) read Riva as a cross-gendered stand-in for the author, a variation on a gay male queen, an interpretation the similarity of "Rive" and "Riva" reinforces.

87 Rive, "Riva," 69.

88 Ibid, 70 .

89 Ibid.

90 Jacob Dlamini, Native Nostalgia (Johannesburg: Jacana Press, 2009), 20-21.

1 The cover photograph of the District Six Museum's volume, City, Site, Museum, is representative: a large rock in the foreground, an expanse of grasses and "empty" land stretches toward the tall buildings of Cape Town's center.

2 See, for example, an article in a paper published by Cape Town's Central City Improvement District: "The Evolution of the East City: The Precinct of Possibilities," City Views (Winter 2018), 4. A new “East City” apparently encompasses what was the western part of the District.

3 On Heritage Day, in September 2019, Keizersgracht was ("re")named Hanover Street. The District Six Museum and others publically contested this decision, viewing it as a token gesture which contributed to the erasure of the historical Hanover Street.

4 "The Six," a local (now archaic) Afrikaans name for the District.

5 Mrs. Mymoena Abrahams, in conversation with the author November 19, 2012, District Six. The transcribed text that follows is drawn from that recorded exchange.

6 Although the social history of cinema and cinema-going in South Africa is not a focus of this study, interested readers might consult, in addition to Bill Nasson's previously cited essay focused on District Six, a recent study of black-centered film and black film-going culture in South Africa: Litheko Modisane, South Africa's Renegade Reels: The Making and Public Lives of Black-Centered Films (New York: Palgrave MacMillan, 2014). For an intriguing, although fleeting, reference to "bioscopes" in the pre-apartheid Cape Town township of Kwa-Ndabeni, see the October 19, 2008 interview with Philis Fuku, October 19, 2008, cited in Sipokazi Sambumbu, "Social History, Public History, and the Politics of Memory in Re-making 'Ndabeni's' Pasts,” Master's Thesis, University of the Western Cape, 2010, 144.

7 Carol Petersen and Margaret Hendricks, in conversation with the author, November 1, 2012, Cape Town. The transcribed text that follows is drawn from that recorded exchange.

8 Puah Gamsu, in conversation with the author, December 22, 2012, Cape Town. The transcribed text that follows is drawn from that recorded exchange.

9 Issa Ndoye, in conversation with the author, March 17, 2013, Thiaroye. The transcribed text that follows is drawn from that recorded exchange.

10 Penc is typically translated as a "village meeting place." The Thiaroye penc I reference are open-air cement shelters on the beach. A gaal is a slim wooden fishing boat (in French, un pirogue). 
11 Mamadou Diouf notes the emphasis on fishing found in the rare ethnographic studies devoted to the Lebu ("Identité ethnique et vie politique municipale. Les Lébu de Rufisque (1945-1960)," in Les Ethnies ont une histoire, eds. Jean-Pierre Chrétien and Gérard Prunier (Paris: Karthala, 1989), 285); the contemporary popular association between fishing and "Lebuness" is ubiquitous.

12 One elderly resident recounted how screenings were available for free to those children, like himself, who climbed nearby palms and watched films from above the enclosing walls. Most residents, however, who were born long after the cinema closed, seemed only to know that there once was a cinema.

13 Other Lebu villages on the Cap Vert Peninsula, such as Yoff, Ouakam, and Ngor, have likewise been subsumed into the metropolis of Dakar and have sold or lost much of their land.

14 Since 1996, four départements have composed the "région" of Dakar, which encompasses the Cap Vert peninsula. In territory and population, the département of Pikine is the largest; its population alone exceeds one million. The total population of Dakar (la région de Dakar) is close to three million. As of 2015 , the population of Thiaroye-sur-Mer was 50,390 and the population of nearby Thiaroye Gare was 29,825. The larger municipal entity, the arrondissement of Thiaroye, had a population of almost 300,000. See http:// senegal.opendataforafrica.org.

15 In Mamadou Diouf's analysis, the passage of the loi Blaise Diagne constituted a key moment in the "invention" of Lebu ethnicity, the event which initiated the formation of a Lebu identity on the peninsula. "Identité ethnique et vie politique municipale," 294.

16 Diouf, "Identité ethnique et vie politique municipale," 292.

17 After 1960, the newly independent Senegalese state would engage with official Lebu representatives, even as it asserted rights over all land that lacked formal title.

18 "Ainsi bien avant l'avènement de la 1ère République lébou vers 1789 et celui de la 1ère République Française en 1790, ils se retirèrent pour s'implanter à Thiaroye Kao à côté du lieu où se trouve aujourd'hui le lac Wekhet, site qui présentait pour eux l'endroit idéal pour paître et abreuver leurs troupeaux." (Thus, well before the establishment of the First Lebu Republic toward 1789, and that of the First French Republic in 1790, they [Thiaroye villagers] withdrew to settle in Thiaroye Kao ["High" or "Inland" Thiaroye], beside which today Lake Wekhet is located, an ideal site for the pasturing and watering of their flocks.) Assemblée Générale de l'Association des Freys de Thiaroye s/ mer, Rapport introductif (November 2, 2008, Dakar), 4.

19 Ibid.

20 Colonial authorities in Dakar initiated a large-scale effort to segregate the city and expropriate land, eradicating certain Lebu villages completely, and creating central Dakar's segregated Médina in 1916. Africans accurately viewed public health concerns as pretexts for dispossession, understood, at least in part, as revenge for Blaise Diagne's recent electoral victory. See Elikia M'Bokolo, "Peste et société urbaine à Dakar: l'épidémie de 1914," in "Études épidémiologiques et approches géographiques des maladies en Afrique tropicale. Mélanges pour un dialogue," special issue, Cahiers d'Études africaines 22, no. 85/86 (1982): 13-46 and Myron Echenberg, Black Death, White Medicine: Bubonic Plague and the Politics of Public Health in Colonial Senegal, 1914-1945 (Portsmouth, NH: Heinemann, 2002).

21 A comparison is illustrative. The first bubonic plague outbreak of the twentieth century in the Atlantic World figures in both the Freys' account, and-as 
we saw in Chapter 2-in the District Six Museum's Digging Deeper exhibition. Plague traveled from port city to port city; in both Cape Town and Dakar, it was a pretext for racialized dispossession and forced relocation. In the Freys' historical account, this plague outbreak is mentioned only in passing as the reason for the village's penultimate relocation. No mention is made of colonial force. By contrast, in the "memory" that the District Six Museum represents, the epidemic of 1901 is critical. Its instrumentalization by a white supremacist colonial administration is explained, and the forced removal of 1901 becomes foundational in the "memory" of racism and community that we are to assimilate.

22 The Waalo is a predominantly Wolof-speaking region, once an independent Wolof kingdom, in contemporary northern Senegal. A "Waalo-Waalo" is a person from the Waalo.

23 Although at least two of my interlocutors were young adults at the time, no one I spoke with said they participated in or witnessed the violence.

24 El Haj, in conversation with the author, March 6, 2013, Thiaroye. The transcribed text that follows is drawn from that exchange.

25 Six people are killed, according to El Haj and newspaper reports of the time (see Paris-Dakar, September 18, 1948, Archives Nationales du Sénégal, Dakar, Senegal); El Haj does not name the identity of the sixth person.

26 "Dañu ko attaquer parce que dafa ànd ak chef de village bi, maanaam protéger ko" (They attacked him [Ndiaye] because he supported, that is to say protected, the chef de village).

27 Galandou Diouf died in 1941. It is unclear to me why El Haj's explanation so emphasizes his role in provoking the killings, given the years and events which intervened between 1941 and 1948. Mamadou Diouf's essay on the "invention" of Lebu ethnicity suggests more proximate reasons for the killings: the formation of Lebu ethnic sentiment in the general aftermath of the 1946 loi Lamine Gueye and, in the specific aftermath of the 1948 election of Dakar's deputy mayor. When the Lebu-supported candidate for deputy mayor lost the municipal elections, Lebu accused Gueye-then mayor of Dakar as well as representative to the National Assembly-of having obtained the right to vote for "natives" in order to ensure his own continued occupancy of the mairie since, with rapid urbanization, newly enfranchised migrants would shortly become an electoral majority in Dakar. In the aftermath of this electoral defeat a new-in effect, ethnic-association formed, that of the [Lebu] Communauté $d u$ Cap-Vert; as well, an ethnically inflected massacre took place ("Identité ethnique et vie politique municipale," 294).

28 M.M. Prevaudeau, "A Thiaroye : le cinéma dans la nature," Paris-Dakar, December 13, 1948, 3.

29 Betty Fall, "Colobane voudrait aussi un cinéma," Paris-Dakar, November $15,1948,2$.

30 See Ivy Mills, “Sutura,” 118-66.

31 Such, sometimes lethal, violence also takes the form of making HIV medication impossible to access and the, extremely violent, language about and directed toward góor-jigéen in everyday life and in the media.

1 In late 2012, amid widespread rumors of intimidation and corruption surrounding the Trust, residents would repeat to me variations on a word-play: We have lost trust in the Trust, there is no trust in the Trust.

2 Louise Bethlehem, Skin Tight: Apartheid Literary Criticism and Its Aftermath (Pretoria: UNISA Press, 2006), 11. 
3 Eileen Julien critiques the dominant reception of canonical-predominantly realist-Europhone African novels thus:

[...] African novels taught in schools on the continent and abroad continue to be extroverted novels that have tended to explain Africa to the world, and especially to a hegemonic West. [. . .] And since realism in African novels has tended to be taken at face value as an unmediated reflection of life in Africa, it is this novelistic theme and representation of the continent that have come to dominate perception of it on the outside.

"The Extroverted African Novel" The Novel, vol. 1 (Princeton, NJ: Princeton University Press, 2006), 695

4 Bethlehem, Skin Tight, 12.

5 Thiaw, "L'Espace entre les mots et les choses," 18.

6 Bethlehem, Skin Tight, 12. Regarding the "representational realism" that South African literary scholarship came to share with South African revisionist historical scholarship, Bethlehem writes,

[. . .] the very modelling of oppositional literary criticism on contemporary revisionist or radical historical practices sustains evidence of a thorough-going critical 'will to power' over the exteriority of social life under apartheid, that is to say, a reinscription of the desire to close the gap between the word and the world.

(Ibid)

7 Nigel Worden, Elizabeth van Heyningen, and Vivian Bickford-Smith, Cape Town: The Making of a City, An Illustrated Social History (Cape Town: David Philip, 1998).

8 As the cover image, it also constitutes a bit of visual word-play. The Making of a City is the first volume of a two-volume history of Cape Town; this first volume begins with Dutch rule and leaves us at the threshold of the twentieth century, at the moment of the painting's completion.

9 Carole Silver, "Images of Empire: Art and Artifacts in Cape Town, South Africa," Victorian Literature and Culture 34, no. 1 (2006), 338. I am indebted to Silver's essay and to the Iziko National Gallery Holiday Time file notes, particularly for their detailed descriptions of the painting.

10 For a brief discussion of this temporality, see Nicolaas Vergunst, Hoerikwaggo: Images of Table Mountain (Cape Town: South African National Gallery, 2001), 83. Vergunst cites unpublished exhibit notes (1999) authored by Hayden Proud, curator at the South African National Gallery.

11 Silver, "Images of Empire," 338.

12 Ibid, 332. Silver also identifies the two politicians and suggests others would have been identifiable to contemporary viewers.

13 Ibid, 340.

14 Silver suggests the location of the two figures is ironic and that the woman "may well be a prostitute" (Ibid).

15 "Frank Fillis," Encyclopaedia of South African Theatre, Film, Media and Performance (ESAT). http://esat.sun.ac.za/index.php/Frank_Fillis. The choice of final verb (import) suggests the long life of white supremacy.

16 The description of the painting in the National Gallery file describes the rondavels as "the huts of scantily clad Hottentot workers."

17 Hanging in the National Gallery in Cape Town, it was, however, according to Silver, perennially popular ("Images of Empire," 336). 
18 The catalogues of two post-apartheid exhibitions in the National GalleryHoerikwaggo (2001) and Patterns of Contact (2004)-reproduce the painting but say little about it. In the latter, there is no attempt to draw the painting into the overarching theme of "contact."

19 This was also the case when, in the same house, I was shown District Six: The Musical so that I would better understand how the District really was. The fact that the musical was not factual, and presents an almost allegorical drama of the District and its destruction, was irrelevant to its value as a source.

20 Sean Field, Oral History, Community, and Displacement: Imagining Memories in Post-apartheid South Africa (New York: Palgrave Macmillan, 2012), 25-6.

21 Alassane Ndaw (1922-2013) taught for many years at the Université de Dakar and served for six years as the dean of the university's faculty of humanities and social sciences, the first African scholar to do so.

22 Ndaw, in conversation with the author, February 15, 2013, Dakar. The transcribed text that follows is drawn from that recorded exchange.

23 The official claim remains that the military believed that the tirailleurs had been subject to German propaganda while German prisoners of war and were therefore dangerous. See, for example, Doudou Diallo's account: "L'Aube tragique du 1ère décembre 1944 à Thiaroye," Afrique histoire 7 (1983), 51.

24 "A un moment donné, on nous avait dit, on a demandé sept hommes avec un gradé et d'aller à Thiaroye, comme j'étais brigadier-chef, j'étais chef de poste, j'ai pris un revolver, et puis j'ai pris 6 hommes, tous des blancs et je suis allé au poste de police où se trouvait un Français." (At a particular moment, they told us, they asked for seven men, with one ranking man, to go to Thiaroye. As I was a sergeant, I was chef de poste, I took a revolver, and then I took six men, all whites, and I went to the guard post where there was a French man.)

25 Jacques Ranicière, Film Fables, trans. Emiliano Battista (Oxford: Berg, 2006), 143.

26 Ibid, 145.

27 Ibid, 152.

28 Mao Zedong, Le Petit Livre rouge : Citations de Mao Tsétoung (pages unnumbered). https://chine.in/fichiers/petit-livre-rouge.pdf.

29 Blondin Diop also appeared briefly in Godard's 1968 (English-language) film Sympathy for the Devil (also titled One Plus One).

1 The "younger" periodical's existence spanned 17 issues, beginning in March 1954 and ending in July 1955. "Drum's Younger Sister" was the subtitle of Africa! during its first nine issues (March-Nov. 1954). While Drum has received a great deal of scholarly attention, its short-lived "sister" has not.

2 For more on the Pan-Africanism of Drum, see Tom Odhiambo, "Inventing Africa in the Twentieth Century: Cultural Imagination, Politics and Transnationalism in Drum Magazine," African Studies 65, no. 2 (2006): 157-74 (doi: 10.1080/00020180601035625).

3 Africa! ceased publication near the same juncture that Drum ceased to function as a forum for black literary writing. With the departure of chief editor Anthony Sampson in 1957, the short story contest ended and Drum came to focus almost exclusively on the popular, ostensibly apolitical, areas of popular culture and sports. 
4 "Message from an African," The African Drum, March 1951. Drum was initially known as The African Drum.

5 Lindsay Clowes's analysis of the submissions to the Drum beauty contests (1951-53) and the responses of the magazine provides a fascinating glimpse of how magazine staff, black and white, enforced their iteration of Western norms of gender and beauty on the very different conceptions that reader submissions reflected (“'Are you going to be MISS (or MR) Africa?' Contesting Masculinity in Drum Magazine 1951-1953?” Gender and History 13, no. 1 (April 2001): 1-20).

6 Jim Bailey, Kenya: The National Epic (Nairobi: Kenway Publications, 1993), iv, as cited in Odhiambo, "Inventing Africa in the Twentieth Century," 158.

7 Leaders of African nations-to-be are profiled and interviewed, and themselves write; even the Bandung Conference, notwithstanding Bailey's ardent anti-Communism, is briefly covered.

8 Africa!, July 1955, 10.

9 Njabulo Ndebele, "The Rediscovery of the Ordinary: Some New Writings in South Africa," Journal of Southern African Studies 12, no. 2 (1986): 143-57.

10 In his memoir, Rive recounts that Barney Desai, PAC activist and then editor of The Golden City Post, commissioned the story and implies that Desai created the pseudonym as part of the story's title: "He commissioned me to do a feature article entitled, 'My Sister Was a Playwhite by Mary X'. When I had finished this 'true confession' I took it to his office at Castle Bridge [. . .]” (Writing Black (Cape Town: David Philip, 2013), 21). Rive does not explain how the story came to be published in Africa!; both publications, however, were a part of the Drum empire.

11 Richard Rive, "My Sister Was a Playwhite by Mary X," Africa!, no. 17 (July 1955), 27.

12 Ibid.

13 Ibid.

14 Ibid, 28.

15 Ibid.

16 Ibid, 29.

17 Ibid, 31.

18 Ibid.

19 Ibid.

20 In contemporary Capetonian Gayle, the coded way of speaking associated with Coloured gay Capetonian life, "Mary" refers to an obvious homosexual, presumably in a borrowing from Anglo-American gay slang ("Oh, Mary," "Muscle Mary"). The gay male cultural connotations of "Mary" are similarly apt for the character of the same name in Rive's 1986 novel.

21 In 1971, the first law on the transcription of "national languages" was passed (six "national languages" had been recognized in 1968). Cultural production in languages other than French potentially threated both and the continued monopoly of public discourse by a French-educated elite and that elite's conception of the Senegalese nation. As Tobias Warner puts it in his discussion of the controversy over the spelling of the title of Sembène's 1976 film, "Far from being a diversion, the quarrel over how to spell ceddo was a struggle over who could claim the authority to define the ceddo-Sembène or the state" (The Tongue-Tied Imagination, 149). For Warner's analysis of the language legislation, and its application to Sembène's film Ceddo in particular, see pages 14351. See also Mamadou Cissé, "Langue, Etat et société au Sénégal," Revue électronique internationale de sciences du langage Sudlangues no. 5 (2006): 99-133. http://www.au-senegal.com/IMG/pdf/doc-109pdf-33f96.pdf. 
22 Founded by Magatte Thiam, Samba Diouldé Thiam, and Mamadou Diaformer prime minister and recently released political prisoner-And Soppi first appeared in 1977. It was in the pages of And Soppi that Cheikh Faty Faye's play about the Thiaroye Massacre appeared in installments in 1977 and 1978.

23 As I noted in Chapter 2, in Mamadou Diouf's analysis, the censorship of Ceddo was provoked by the pointed relevance of its historical engagement for the political present: the true source of the state's objection was Sembène's implied critique of the Senghorian national present. See "Histoire et actualités dans CEDDO d'Ousmane Sembène et HYENES de Djibril Diop Mambéty," 15-34.

24 The first issue of Siggi was numbered zero; thus Diagne's interview, in issue number two, is located in the journal's third issue: Siggi no 2. (Feb. 1977): 17-21.

25 Pathé Diagne, “Siggi Nag Faf,” Siggi, no. 2 (February 1977), 17.

26 Ibid.

27 Phonological oppositions, between strong (doubled) consonants and weak consonants (or long vowels), create antonym pairs.

28 Diagne, "Siggi Nag Faf," 17.

29 "Accepter par ailleurs de distinguer sëgg et sëg, et proscrire siggi au profit de sigi; c'est naturaliser l'incohérence : comme en français où l'on écrit nommer et nomination." (To accept the distinction between sëgg and sëg, but to prohibit siggi in favor of sigi; this would be to naturalize incoherence, as in French when one writes nommer and nomination.) (Ibid).

30 Diagne, "Siggi Nag Faf," 17.

31 Ibid.

32 "Seen" becomes, when written according to French orthographic conventions, the familiar Seneglese family name "Sène." Current Wolof spelling conventions, according to Jean-Léopold Diouf's Dictionnaire wolof-français et français-wolof would require "ngóor," rather than, as in Diagne's piece, "ngoor."

33 Diagne, "Siggi Nag Faf," 18.

34 In Wolof, only the originaires of Ndar are referred to in this way; one would not refer to the "child" of another city or region: no one is for example, a doomu Ndakaaru, a child of Dakar.

35 Diagne, "Siggi Nag Faf," 18.

36 Joop is a typically Wolof name (in French transcription, "Diop"), and Saar (in French transcription, "Sarr"), a typically Sereer name. Fara and Ancumaan are men's names.

37 Diagne, "Siggi Nag Faf," 18.

38 I am grateful to Souleymane Bachir Diagne who recounted the anecdote of the vendor during our discussions of Siggi and "Siggi Nag Faf."

1 François Hollande, "Discours de M. le Président de la République devant l'Assemblée nationale de la République du Sénégal," Dakar, October 12, 2012.

2 A fourth presidential speech, not referred to in the media as occurring "en marges du Sommet," was addressed to Dakar's French expatriate community.

3 François Hollande, "Discours à l'occasion de l'ouverture du XVème Sommet de la Francophonie à Dakar,” Dakar, November 29, 2014.

4 François Hollande, "Discours au cimitière de Thiaroye." Dakar, November 30, 2014.

5 Hollande, “Discours au cimitière de Thiaroye," 2014. 
6 “Aujourd'hui les interrogations demeurent : celles des historiens, celles des familles, celles finalement de tous ceux qui veulent comprendre. D'abord sur le nombre exact de victimes, mais aussi sur l'endroit où ils furent inhumés qui reste encore mystérieux." (Today questions [still] remain: those of historians, those of the families, and, finally, those of all who seek to understand. First of all, regarding the exact number of victims, but also regarding the place where they were buried, which still remains mysterious.)

7 “La France n'a pas oublié et n'oubliera jamais ce qu'elle doit à l'Afrique. C'est pourquoi elle est présente aujourd'hui pour lutter contre le terrorisme, partout où il sévit, où il menace des peuples libres." (France has not forgotten, nor will she ever forget, what she owes to Africa. That is why she is present today in the fight against terrorism, wherever it strikes, wherever it threatens free peoples.)

8 There are 11 signatory organizations; the first, and the only to be based in Senegal, consists of a group of Senegalese political parties that includes the Rassemblement nationale démocratique, the party founded by Cheikh Anta Diop in 1976. The remaining ten are located in other African countries, with the exception of the Union calédonnienne - Front de libération nationale Kanak et socialiste and the Groupe de recherche et d'Initiative pour la libération de l'Afrique (GRILA), based in Montréal.

9 "Déclaration commune : vérité et justice pour les victimes du massacre de Thiaroye," Le Calame, November 30, 2017. http://www.lecalame.info/?q= node/6541. (While dated November 30, 2017, the eve of the anniversary, the letter is signed December 1, 2017).

10 Republic of South Africa, National Heritage Resources Act (No. 25 of 1999).

11 Mattera, Memory Is the Weapon, 152.

12 Ibid.

13 Corespondents include the Land Claims Commissioner, the District Six Beneficiary and Redevelopment Trust, and the City of Cape Town.

14 Eighty percent of land claims (969) submitted during the initial claims period (1995-98) have not been settled (Claims from the same period for financial compensation in lieu of land have been settled). No claims submitted during the second submission period (2014-16) have been settled. Christina Pitt, "Still no Response from Land Reform Minister to District Six Working Committee Application,” news24, April 30, 2018.

15 "Didiza Submits Detailed Plan for District Six Redevelopment," SA People News, December 19, 2019. https://www.sapeople.com/2019/12/19/ didiza-submits-detailed-plan-for-district-six-redevelopment/. 


\section{Bibliography}

Adhikari, Mohamed, ed. Not White Enough, Not Black Enough: Racial Identity in the South African Coloured Community. Athens: Ohio University Press, 2005.

Angrand, Armand-Pierre. Les Lébous de la prequ'île du Cap-Vert : essai sur leur histoire et leurs coutumes. Dakar: E. Gensul, [1946?].

Association sénégalaise des professeurs d'histoire et de géographie. "Profanation - Tombes des victimes de Thiaroye 1944, L'autoroute à péage " passe sur les sépultures »." Le Quotidien, December 5, 2006, 3.

Baderoon, Gabeba. Regarding Muslims: From Slavery to Post-apartheid. Johannesburg: Wits University Press, 2014.

Bady, Aaron. "Robben Island University." In "Nelson Rolihlahla Mandela 1918-2013," special issue, Transitions no. 116 (2014): 106-19.

Bailey, Jim. Kenya: The National Epic. Nairobi: Kenway Publications, 1993. As cited in Odhiambo, "Inventing Africa in the Twentieth Century," African Studies, 158.

Barnett, Naomi. "Race, Housing and Town Planning in Cape Town, c. 19201940, with Special Reference to District Six.” Master's Thesis, University of Cape Town, 1993.

Barry, Boubacar. Le Royaume du Waalo : le Sénégal avant la conquête. Paris: Karthala, 1985.

Bathily, Abdoulaye. Interview by Falilou Ndiaye, Manfred Prinz, and Alioune Tine. In Ndiaye, Prinz, and Tine, Visages publics du Sénégal, 113-31.

Bennett, Bonita and Chrischené Julius, "Where Is District Six? Between Landscape, Site and Museum." In Bennett, Julius, and Soudien, City, Site, Museum, 52-67.

Bennett, Bonita, Chrischené Julius, and Crain Soudien, eds. City, Site, Museum: Reviewing Memory Practices at the District Six Museum. Cape Town: District Six Museum, 2008.

Berliner, David. "The Abuses of Memory: Reflections on the Memory Boom in Anthropology." Anthropology Quarterly 78, no. 1 (2005): 197-211.

Bernard, Philippe. "Les Sénégalais retrouvent la mémoire.” Le Monde, February 23, 2006.

Bethlehem, Louise. Skin Tight: Apartheid Literary Criticism and Its Aftermath. Pretoria: UNISA Press, 2006.

Bèye, Ben Diogaye and Boubacar Boris Diop. Thiaroye 44. Scénario inédit. Paris: L'Harmattan, 2018. 
Beyers, Christiaan. "The Cultural Politics of 'Community' and Citizenship in the District Six Museum, Cape Town.” Anthropologica 50, no. 2 (2008): 359-73.

Bickford-Smith, Vivian. "The Origins and Early History of District Six to 1910." In Jeppie and Soudien, The Struggle for District Six, 35-43.

_. "Writing about Englishness: South Africa's Forgotten Nationalism." In Empire and After: Englishness in Postcolonial Perspective, edited by Graham McPhee and Prem Poddar, 57-72. New York and Oxford: Berghahn Books, 2007.

Bickford-Smith, Vivian, Sean Field, and Clive Glaser. "The Western Cape Oral History Project: The 1990s." African Studies 60, no. 1 (2001): 5-23.

Bocoum, Hamady and Bernard Toulier. "La Fabrication du patrimoine : l'exemple de Gorée (Sénégal).” In Situ 20 (2013): 2-30. http://insitu.revues.org/10303.

Boroom Jamono Yi [pseudonym]. “Xewoonu Mee.” Kaddu no. 20 [May, 1974?]: 9. Bottaro, Jean, Pippa Visser, and Nigel Worden. In Search of History. Grade 11, Learner's Book. Cape Town: Oxford University Press Southern Africa, 2006.

Burns, James. "The African Bioscope - Movie House Culture in British Colonial Africa." Afrique \& histoire 1, no. 5 (2006): 65-80.

Camara, Abdoulaye and Joseph-Roger de Benoist. Gorée : guide de l'île et $d u$ Musée historique. Dakar: IFAN-Cheikh Anta Diop, 1993.

Ceddo [pseudonym, likely Ousmane Sembène]. “Moom Sa Réew.” In “Independaas," special issue, Kaddu (April 1972): first (unnumbered) page.

Césaire, Aimé. Discours sur le colonialisme. Paris: Présence africaine, 2004. First published 1950 by Présence africaine (Paris).

—. Discourse on Colonialism, translated by Joan Pinkham. New York: Monthly Review Press, 2000. First published 1979 by Monthly Review Press (New York).

Chapman, Michael. "More than Telling a Story: Drum and Its Significance in Black South African Writing." In The Drum Decade: Stories from the 1950s, edited by Michael Chapman, 183-227. Pietermaritzburg: University of Natal Press, 1989.

Cissé, Mamadou. "Langue, Etat et société au Sénégal.” Revue électronique internationale de sciences du langage Sudlangues no. 5 (2006): 99-133. http:// www.au-senegal.com/IMG/pdf/doc-109pdf-33f96.pdf.

Clowes, Lindsay. “'Are You Going to be MISS (or MR) Africa?’ Contesting Masculinity in Drum Magazine 1951-1953?” Gender and History 13, no. 1 (April 2001): 1-20.

- "Masculinity, Matrimony and Generation: Reconfiguring Patriarchy in Drum 1951-1983." Journal of Southern African Studies 34, no. 1 (2008): 179-92.

Coombes, Annie. "District Six: The Archeology of Memory.” In History after Apartheid: Visual Culture and Public Memory in a Democratic South Africa, 116-48. Durham, NC: Duke University Press, 2003.

Deacon, Harriet. "Intangible Heritage in Conservation Management Planning: The Case of Robben Island.” International Journal of Heritage Studies 10, no. 3 (2004): 309-29.

Department of Education, Republic of South Africa. National Curriculum Statement, Grades 10-12 (General) History. Pretoria: Department of Education, 2005.

Diagne, Pathé. “Siggi Nag Faf.” Siggi no. 2 (February 1977): 17-21. 
Diagne, Souleymane Bachir. Léopold Sédar Senghor : l'art africain comme philosophie. Paris: Riveneuve Editions, 2007.

- "In Praise of the Post-racial: Negritude Beyond Negritude." Third Text 24, no. 2 (2010): 241-8.

—. "Senghor et la question qui se pose toujours." Interview by Nadia Yala Kisukidi. ThéoRèmes 4 (Nov. 2013). http://theoremes.revues.org/430.

Diop, Abdoulaye Bara. La Société wolof: les systèmes d'inégalité et de domination. Paris: Karthala, 1981.

Diop, Boubacar Boris. Le Temps de Tamango suivi de Thiaroye terre rouge. Paris: L'Harmattan, 1981.

Diop, Madia. Interview by Falilou Ndiaye and Manfred Prinz. In Ndiaye, Prinz, and Tine, Visages publics du Sénégal, 192-205.

Diop, Momar-Coumba and Mamadou Diouf, eds. Le Sénégal sous Abdou Diouf : Etat et société. Paris: Karthala, 1990.

Diouf, Mamadou. "Essai sur l'histoire du Saalum.” Revue sénégalaise d'Histoire 2, no. 1 (1981): 25-37.

—. "Identité ethnique et vie politique municipale. Les Lébus de Rufisque (1945-1960).” In Les Ethnies ont une histoire, edited by Jean-Pierre Chrétien and Gérard Prunier, 283-301. Paris: Karthala, 1989.

- Le Kajoor au XIXe siècle: Pouvoir ceddo et conquête coloniale. Paris: Karthala, 1990.

—. "Histoire et actualités dans CEDDO d'Ousmane Sembène et HYENES de Djibril Diop Mambéty." In Littérature et cinéma en Afrique francophone: Ousmane Sembène et Assia Djebar, edited by Sada Niang, 15-34. Paris: L'Harmattan, 1996.

Dlamini, Jacob. Native Nostalgia. Johannesburg: Jacana Media, 2009.

Echenberg, Myron. "Tragedy at Thiaroye: The Senegalese Soldiers' Uprising of 1944." In African Labor History, edited by Peter Gutkind, Robin Cohen, and Jean Copans, 109-28. Beverley Hills: Sage Publications, 1978.

- "Morts Pour la France'; The African Soldier in France during the Second World War." The Journal of African History 26, no. 4, World War II and Africa (1985): 363-80.

- Colonial Conscripts: The Tirailleurs Sénégalais in French West Africa, 1857-1960. Portsmouth, NH: Heinemann, 1991.

. Black Death, White Medicine: Bubonic Plague and the Politics of Public Health in Colonial Senegal, 1914-1945. Portsmouth, NH: Heinemann, 2002.

Erasmus, Zimitri, ed. Coloured by History, Shaped by Place: New Perspectives on Coloured Identities in Cape Town. Cape Town: Kwela Books, 2001.

- "Introduction: Reimagining Coloured Identities in Post-apartheid South Africa." In Eramus, Coloured by History, 13-28.

- "Rearranging the Furniture of History: Nonracialism and Anticolonial Praxis." Critical Philosophy of Race 5, no. 2 (2017): 198-222.

Fall, Betty. "Colobane voudrait aussi un cinéma.” Paris-Dakar, November 15, 1948, 2 .

Farred, Grant. Midfielder's Moment: Coloured Literature and Culture in Contemporary South Africa. Boulder, CO: Westview Press, 2000.

Faye, Cheikh Faty. Aube de sang. Paris: L'Harmattan, 2005.

Ferguson, James. "The Uses of Neoliberalism," Antipode 41, no. S1 (2009): 166-84. doi: 10.1111/j.1467-8330.2009.00721.x. 
Field, Sean, ed. Lost Communities, Living Memories: Remembering Forced Removals in Cape Town. Cape Town: David Philip, 2001.

- Oral History, Community, and Displacement: Imagining Memories in Post-apartheid South Africa. New York: Palgrave Macmillan, 2012.

Frederikse, Julie. The Unbreakable Thread: Non-racialism in South Africa. Cape Town: Ravan Press, 1990.

Godard, Jean-Luc. La Chinoise. Paris: Productions de la Guéville, 1967.

Goldblatt, Cullen. "Toward the Space between Words and Things: Omar Blondin Diop (Died in Detention)." In "Cartographies of Dissent," special issue, English Language Notes 52, no. 2 (Fall/Winter 2014): 163-84.

—. "Beyond the 'Memory' of Apartheid: Richard Rive and the Jewish Mock Monarchs of Cape Town.” Journal of Postcolonial Writing 53, no. 4 (2017): 454-68. doi: 10.1080/17449855.2017.1307259.

- "Imperial Humanist Critique on the Margins of African Canons." Interventions: International Journal of Postcolonial Studies (2020, print forthcoming). doi: 10.1080/1369801X.2020.1718533.

Graham, Shane and John Walters, eds. Langston Hughes and the South African Drum Generation: The Correspondence. New York: Palgrave Macmillan, 2010.

Grunebaum, Heidi. Memorializing the Past: Everyday Life in South Africa after the Truth and Reconciliation Commission. New Brunswick, NJ: Transaction Publishers, 2011.

Gueye, Mbaye. "Le 1ère décembre 1944 à Thiaroye ou le massacre de tirailleurs sénégalais anciens prisoniers de guerre." Revue sénégalaise d'Histoire, 1 (1995): 3-23.

Gqola, Pumla Dineo. What Is Slavery to Me? Postcolonial/Slave Memory in Post-apartheid South Africa. Johannesburg: Wits University Press, 2010.

Hall, Martin. "Subaltern Voices? Finding the Spaces between Things and Words." In Historical Archaeology: Back from the Edge, edited by Pedro Paulo, A. Funari, Martin Hall, and Sîan Jones, 193-203. London: Routledge, 1999.

Harrow, Kenneth. "Camp de Thiaroye: Who's That Hiding in Those Tanks and How Come We Can't See Their Faces?” IRIS 18 (1995): 147-52.

Hart, Deborah M. "Political Manipulation of Urban Space: The Razing of District Six, Cape Town.” In Jeppie and Soudien, The Struggle for District Six, 117-42.

Hart, Gillian. Rethinking the South African Crisis: Nationalism, Populism, Hegemony. Scottsville: University of KwaZulu-Natal Press, 2012.

Hertzberger-Fofana, Pierrette. "Joseph Ndiaye (1922-2009), la voix de la maison des esclaves de Gorée s'est éteinte," Grioo.com, October 2, 2009. http:// mobile.grioo.com/article.php?id=16316.

Hinchman, Mark. Portrait of an Island: The Architecture and Material Culture of Gorée, Senegal, 1758-1837. Lincoln: University of Nebraska Press, 2015.

Hollande, François. “Discours de M. le Président de la République devant l'Assemblée nationale de la République du Sénégal.” October 12, 2012, Dakar. https://www.jeuneafrique.com/173903/politique/france-afrique-le-texte-dudiscours-de-dakar-prononc-par-fran-ois-hollande/.

—. "Discours à l'occasion de l'ouverture du XVème Sommet de la Francophonie à Dakar.” Dakar, November 29, 2014.

—. "Discours au cimetiere de Thiaroye." Dakar, November 30, 2014. 
Hughes, Langston, ed. An African Treasury: Articles, Essays, Stories, Poems, by Black Africans. New York: Crown Publishers, 1960.

- ed. Poems from Black Africa. Bloomington: Indiana University Press, 1963.

Jeppie, Shamil and Crain Soudien, eds. The Struggle for District Six: Past and Present. Cape Town: Buchu Books, 1990.

Julien, Eileen. "The Extroverted African Novel." In The Novel, Vol. 1: History, Geography, and Culture, edited by Franco Moretti, 667-700. Princeton, NJ: Princeton University Press, 2006.

Julius, Chrischené. "Oral History in the Exhibitionary Strategy of the District Six Museum, Cape Town.” Master's Thesis, University of the Western Cape, 2007.

—. "'Digging Deeper Than the Eye Approves': Oral Histories and Their Use in the Digging Deeper Exhibition of the District Six Museum." Kronos 34, no. 1 (2008): 106-38.

Keïta, Fodéba. Aube africaine. Paris: P. Seghers, 1965.

Klein, Kerwin. "On the Emergence of Memory in Historical Discourse." In "Grounds for Remembering," special issue, Representations 69 (2000): 127-50.

Kramer, David and Taliep Petersen. District Six: The Musical. Cape Town, South Africa, 1987.

Krings, Matthias. "A Prequel to Nollywood: South African Photo Novels and Their Pan-African Consumption in the late 1960s." Journal of African Cultural Studies 22, 1 (2010): 75-89. doi: 10.1080/13696810903488611.

Krouse, Matthew, ed., assisted by Kim Berman. Invisible Ghetto: Lesbian and Gay Writing from South Africa. Johannesburg: Congress of South African Writers, 1993.

Legassick, Martin and Gary Minkley. "Current Trends in the Production of History." Alternation 5, no. 1 (1998): 98-129.

Libre association d'individus libres. Lettre de Dakar. Paris: Champ Libre, 1978.

Lewis, Desiree. "Writing Hybrid Selves: Richard Rive and Zoë Wicomb." In Erasmus, Coloured by History, 131-58.

Lewis, Jack. A Normal Daughter: The Life and Times of Kewpie of District Six. Cape Town: Idol Pictures, 2004.

Lodge, Tom. Sharpeville: An Apartheid Massacre and Its Consequences. New York: Oxford University Press, 2011.

Maart, Rozena. Rosa's District Six. Toronto: Mawzeni House/TSAR Publishers, 2004.

Mabon, Armelle. Prisonniers de guerre "indigènes. "Visages oubliés de la France occupée. Paris: Editions La Découverte, 2010.

Mamdani, Mahmood. Citizen and Subject: Contemporary Africa and the Legacy of Late Colonialism. Princeton, NJ: Princeton University Press, 1996.

-. "A Diminished Truth." In After the TRC: Reflections on Truth and Reconciliation in South Africa, edited by James Wilmot and Linda van de Vijver, 58-61. Athens: Ohio University Press, 2001.

- "Amnesty or Impunity? A Preliminary Critique of the Report of the Truth and Reconciliation Commission of South Africa (TRC)." In "Ethics," special issue, Diacritics 32, no. 3/4 (Autumn-Winter 2002): 32-59.

Mandel, Naomi. Against the Unspeakable: Complicity, the Holocaust, and Slavery in America. Charlottesville: University of Virginia Press, 2006. 
Mao Zedong. Le Petit Livre rouge: Citations de Mao Tsétoung. 1964. Translator unknown. Pages unnumbered. https://chine.in/fichiers/petit-livre-rouge.pdf.

Mattera, Don. Memory Is the Weapon. Johannesburg: African Perspectives Publishing, 2009. First published 1987 by Ravan Press (Johannesburg).

Mauny, Raymond. "En marge du centenaire de l'abolition de l'esclavage, l'île de Gorée," Paris-Dakar, April 22, 1948. Quoted in Bocoum and Toulier. "La Fabrication du patrimoine," In Situ, 6.

M’Bokolo, Elikia. "Peste et société urbaine à Dakar : l'épidémie de 1914." In "Études épidémiologiques et approches géographiques des maladies en Afrique tropicale. Mélanges pour un dialogue," special issue, Cahiers d'Études africaines 22 (1982): 13-46.

Michaels, Walter Benn. "'You Who Never Was There': Slavery and the New Historicism, Deconstruction and the Holocaust." Narrative 4, no. 1 (1996): 1-16.

Millin, Sarah Gertrude. God's Stepchildren. New York: Boni and Liveright, 1924.

Mills, Ivy. "Sutura: Gendered Honor, Social Death, and the Politics of Exposure in Senegalese Literature and Popular Culture.” Ph.D. diss., University of California, Berkeley, 2011 .

Modisane, Litheko. South Africa's Renegade Reels: The Making and Public Lives of Black-Centered Films. New York: Palgrave MacMillan, 2013.

Mourre, Martin. "La Répression de Thiaroye. Décrire les différents degrés de la violence coloniale." Les Temps Modernes 2, no. 693-94 (2017): 87-110.

- Thiaroye 1944. Histoire et mémoire d'un massacre colonial. Rennes: Presses universitaires de Rennes, 2017.

Munro, Brenna. South Africa and the Dream of Love to Come: Queer Sexuality and the Struggle for Freedom. Minneapolis: University of Minnesota Press, 2012.

Murphy, David. Sembène: Imagining Alternatives in Film and Fiction. Trenton, NJ: Africa World Press, 2001. , ed. The First World Festival of Negro Arts: Context and Legacies. Liverpool: Liverpool University Press, 2016.

Murray, Noëleen, Nick Shepherd, and Martin Hall, eds. Desire Lines: Space, Memory and Identity in the Post-apartheid City. New York: Routledge, 2007.

Nasson, Bill. "She Preferred Living in a Cave with Harry the Snake-Catcher: Popular Leisure and Class Relations in District Six, c. 1920s-1950s.” In History Matters: Selected Writings, 165-86. Cape Town: Penguin Books, 2016.

Ndebele, Njabulo. "The Rediscovery of the Ordinary: Some New Writings in South Africa," Journal of Southern African Studies 12, no. 2 (1986): 143-57.

Ndiaye, Boubacar Joseph. Histoire et traite des noirs à Gorée : l'esclavage, ses origines et ses répercussions en Afrique, avec des citations de l'auteur. Dakar: Maison des esclaves, 1986.

- The Slave Trade at Gorée-Island and Its History, Slavery: Its Origins and Consequences in Africa (with Quotations from the Author). Translated by Momar Khary Diagne. Dakar: Maison des esclaves, [1989?].

—. Il fut un jour à Gorée. . . : l'esclavage raconté à nos enfants. Neuilly-surSeine: Michel Lafon, 2006.

Ndiaye, Falilou, Manfred Prinz, and Alioune Tine, eds. Visages publics $d u$ Sénégal : 10 personnalités politiques parlent. Paris: L'Harmattan, 1990.

Non-European Unity Movement. "A Declaration to the Nations of the World, Statement of the Non-European Unity Movement.” Cape Town, July 1945. 
Nora, Pierre. "Between Memory and History: Les Lieux de Mémoire." In "Memory and Counter-Memory," edited by Natalie Zemon Davis and Randolph, special issue, Representations no. 26 (1989): 7-24.

- Les Lieux de mémoire. Paris: Gallimard, 1984-92.

Nuttall, Sarah and Carli Coetzee, eds. Negotiating the Past: The Making of Memory in South Africa. Cape Town: Oxford University Press, 1998.

O'Brien, Donal Cruise, Momar-Coumba Diop, and Mamadou Diouf, eds. La Construction de l'Etat au Sénégal. Paris: Karthala, 2002.

O’Brien, Donal Cruise. "Political Opposition in Senegal: 1960-67." Government and Opposition 2, no. 4 (1967): 557-66. doi: 10.1111/j.1477-7053. 1967.tb01185.x.

- "The Shadow-Politics of Wolofisation." In Symbolic Confrontations: Muslims Imagining the State in Africa, 120-40. New York: Palgrave Macmillan, 2003.

Odhiambo, Tom. "Inventing Africa in the Twentieth Century: Cultural Imagination, Politics and Transnationalism in Drum Magazine." African Studies 65, no. 2 (2006): 157-74. doi: 10.1080/00020180601035625.

Parent, Sabrina. Cultural Representations of Massacre: Reinterpretations of the Mutiny of Senegal. New York: Palgrave Macmillan, 2014.

Pather, Ra'essa. "District Six Claimants Take on Land Reform Minister in Restitution Fight.” Mail \& Guardian, April 24, 2018. https://mg.co.za/article/201804-24-district-six-claimants-take-on-land-reform-minister-in-restitutionfight.

Payne, Suné. "District Six Claimants Ask Court to Force Government to Admit It Failed Them.” Daily Maverick, April 25, 2018. https://www.daily maverick.co.za/article/2018-04-25-district-six-claimants-ask-court-to-forcegovernment-to-admit-it-failed-them/\#.WzIryNOFPVo.

Pfaff, Françoise. "The Uniqueness of Ousmane Sembène's Cinema." In Ousmane Sembène: Dialogues with Critics and Writers, edited by Samba Gadjigo, Ralph H. Faulkingham, Thomas Cassirer, and Reinhard Sander, 14-21. Amherst: University of Massachusetts Press, 1993.

Pimstone, Millie, Milton Shain (convener), and Adrienne Folb. The Jews of District 6: Another Time, Another Place. Cape Town: Kaplan Centre for Jewish Studies and Research, 2012.

Pitt, Christina. "Still no Response from Land Reform Minister to District Six Working Committee Application.” news24, April 30, 2018. http:// www.news24.com/SouthAfrica/News/still-no-response-from-land-reformminister-to-district-6-working committee-court-application-20180430.

Prevaudeau, M.M. “A Thiaroye: Le cinéma dans la nature.” Paris-Dakar, December 13, 1948, 3.

Ranicière, Jacques. Film Fables. Translated by Emiliano Battista. Oxford: Berg, 2006.

Rassool, Ciraj. “Introduction: Recalling Community in Cape Town.” In Rassool and Prosalendis, Recalling Community, vii-xii.

—. "Memory and the Politics of History in the District Six Museum." In Murray, Shepherd, and Hall, Desire Lines, 113-27.

- "The Rise of Heritage and the Reconstruction of History in South Africa.” Kronos no. 26 (August 2000): 1-21. 
Rassool, Ciraj and Sandra Prosalendis, eds. Recalling Community in Cape Town: Creating and Curating the District Six Museum. Cape Town: District Six Museum, 2001.

République du Sénégal. Livre blanc sur le suicide d'Oumar [sic] Blondin Diop. Dakar: Ministère de l'Information et des Relations avec les Assemblées, 1973.

Riesz, János. "Thiaroye 44 : un événement historique et ses représentations littéraires.” In Conflits de mémoire, edited by Véronique Bonnet, 303-19. Paris: Karthala, 2004.

Rive, Richard. "My Sister Was a Playwhite by Mary X.” Africa! no. 17 (July 1955): 27-31.

__. "Riva.” In Advance, Retreat, 60-72. Cape Town: David Philip, 1983.

. 'Buckingham Palace,' District Six. Cape Town: David Philip, 1996. First published 1986 by David Philip (Cape Town).

- Writing Black. Cape Town: David Philip, 2013. First published 1981 by David Philip (Cape Town).

—. "District Six: Fact and Fiction." In Jeppie and Soudien, The Struggle for District Six, 110-6.

Rothberg, Michael. Multidirectional Memory: Remembering the Holocaust in the Age of Decolonization. Stanford, CA: Stanford University Press, 2009.

- The Implicated Subject: Beyond Victims and Perpetrators. Stanford, CA: Stanford University Press, 2019.

Rothberg, Michael, Debarati Sanyal, and Maxim Silverman, eds. "Noeuds de Mémoire: Multidirectional Memory in Postwar French and Francophone Culture." Special Issue, Yale French Studies no. 118/119 (2010).

Samb, Djibril, ed. Gorée et l'esclavage, actes du séminaire sur "Gorée dans la traite atlantique: mythes et réalités” (Gorée, 7-8 avril 1997). Dakar: IFANCheikh Anta Diop, 1997.

Sambumbu, Sipokazi. "Reading Visual Representations of 'Ndabeni' in the Public Realms.” Kronos 36, no. 1 (2010): 184-206.

- "Social History, Public History and the Politics of Memory in Remaking 'Ndabeni”'s Pasts.” Master's Thesis, University of the Western Cape, 2010.

Sanders, Mark. Complicities: The Intellectual and Apartheid. Durham, NC: Duke University Press, 2007.

Sanyal, Debarati. Memory and Complicity: Migrations of Holocaust Remembrance. New York: Fordham University Press, 2015.

Seck, Charles Babacar. Gorée. Guide Touristique. Dakar: SAFER, 1966.

Sembène, Ousmane. Ceddo. Dakar: Film Doomi Reew, 1976.

Sembène, Ousmane and Thierno F. Sow. Camp de Thiaroye. Senegal and Tunisia: SNPC and SATPEC, 1987.

Senghor, Léopold Sédar. "Tyaroye.” In Chants d'ombre suivi de Hosties noires, 143-4. Paris: Editions du Seuil, 1956. First published 1948 by Editions du Seuil (Paris).

-. "Ce que l'homme noir apporte." In Liberté I : Négritude et humanisme, 22-38. Paris: Editions du Seuil, 1964.

- "Préface : De l'île de Gorée à la nation sénégalaise." In La turbulente histoire de Gorée, Jean Delcourt, vii-xii. Dakar: Clairafrique, 1982. 
Shell, Robert C. H. Children of Bondage: A Social History of the Slave Society at the Cape of Good Hope, 1652-1838. Hanover, NH: Wesleyan University Press, 1994.

Silver, Carole G. "Images of Empire: Art and Artifacts in Cape Town, South Africa." Victorian Literature and Culture 34, no. 1 (2006): 335-42. http:// www.jstor.org/stable/25058751.

Simpson, Graeme and Deborah Posel, eds. Commissioning the Past: Understanding South Africa's Truth and Reconciliation Commission. Johannesburg: Wits University Press, 2002.

Soske, Jon. "The Impossible Concept: Settler Liberalism, Pan-Africanism, and the Language of Non-racialism.” African Historical Review 47, no. 2 (2015): 1-36.

Soudien, Crain. "District Six and Its Uses in Discussion about Non-racialism." In Erasmus, Coloured By History, 114-30.

—. "From Protest to Protest." In Jeppie and Soudien, The Struggle for District Six, 143-81.

Sylla, Assane. Le Peuple lébou de la presqu’ile du Cap-Vert. Dakar: Les Nouvelles Editions africaines du Sénégal, 1992.

Thiaw, Ibrahima. "L'Espace entre les mots et les choses : mémoire historique et culture matérielle à Gorée (Sénégal).” In Espace, culture matérielle et identités en Sénégambie, edited by Ibrahima Thiaw, 17-38. Dakar: Codesria, 2010.

Traoré, Mahama Johnson. "Cinema and Freedoms: Reflections of a Senegalese Film-Maker." In African Experiences of Cinema, edited by Imruh Bakari and Mbye B. Cham, 67-9. London: British Film Institute, 1996.

Truth and Reconciliation Commission of South Africa. Truth and Reconciliation Commission of South Africa Report. Vol. 5. Cape Town: Truth and Reconciliation Commission, 1998-2003.

Valley, Dylan. Afrikaaps. Amsterdam: Plexus Films/The Glasshouse, 2010.

Vergunst, Nicolaas. Hoerikwaggo: Images of Table Mountain. Cape Town: South African National Gallery, 2001.

Viljoen, Shaun. "Richard Rive: Non-racialism in a Life of Writing and of Sport." South African Journal for Research in Sport, Physical Education, and Recreation 33, no. 2 (2011): 127-41.

- Richard Rive: A Partial Biography. Johannesburg: Wits University Press, 2013.

Wade, Abdoulaye and M'baye Gana Kébé. Une fresque pour Thiaroye : théâtre. Dakar: Editions Maguilen, 2008.

Ward, Kerry and Nigel Worden. "Commemorating, Suppressing, and Invoking Cape Slavery.” In Nuttall and Coetzee, Negotiating the Past, 201-17.

Warner, Tobias. The Tongue-Tied Imagination: Decolonizing Literary Modernity in Senegal. New York: Fordham University Press, 2019.

Western, John. Outcast Cape Town. Minneapolis: University of Minnesota Press, 1981.

Wicomb, Zoë. "Shame and Identity: The Case of the Coloured in South Africa." In Writing South Africa: Literature, Apartheid and Democracy, 1970-1995, edited by Derek Attridge and Rosemary Jolly, 91-107. Cambridge: Cambridge University Press, 1998.

Wieviorka, Annette. The Era of the Witness. Translated by Jared Stark. Ithaca, NY: Cornell University Press, 2006. 
Williams, James S. “'C'est le petit livre rouge / Qui fait que tout enfin bouge': The Case for Revolutionary Agency and Terrorism in Jean-Luc Godard's La Chinoise." Journal of European Studies 40, no. 3 (2010): 206-18.

Worden, Nigel, Elizabeth van Heyningen, and Vivian Bickford-Smith. Cape Town: The Making of a City, An Illustrated Social History. Vol. 1. Cape Town: David Philip, 1998.

\section{Archival Sources}

Africa!, no. 17. July 1955, Cape Town. National Library of South Africa, Cape Town, South Africa.

African Drum, no. 1. March 1951, Cape Town. National Library of South Africa, Cape Town, South Africa.

District Six Beneficiary and Redevelopment Trust. "Deed of Trust." October 11, 2001. District Six Museum Archives, Cape Town, South Africa.

District Six Museum. "Walk of Remembrance." Pamphlet. Cape Town, District Six Museum, February, 2018.

“District Six Museum Foundation Deed of Trust." April 11, 1994. District Six Museum Archives, Cape Town, South Africa.

Iziko National Gallery. James Ford. Holiday Time in Cape Town in the Twentieth Century in Honour of the Expected Arrival of the Governor-General of United South Africa. File Notes. Cape Town, South Africa.

Kaddu, "Independaas" special issue, April 1972. Archives Nationales du Sénégal, Dakar, Senegal.

Kaddu, no. 20 [1974?]. Archives Nationales du Sénégal, Dakar, Senegal.

Paris-Dakar, September 18, 1948, Dakar. Archives Nationales du Sénégal, Dakar, Senegal.

Paris-Dakar, November 15, 1948, Dakar. Archives Nationales du Sénégal, Dakar, Senegal.

Paris-Dakar, December 13, 1948, Dakar. Archives Nationales du Sénégal, Dakar, Senegal.

“Rapport Introductrice," Assemblée Générale de l'Association des Freys de Thiaroye s/mer. Dakar, November 2, 2008. Pape Diouf's personal papers, Thiaroye, Senegal.

Siggi, no 2. February 1977, Dakar. Archives de l'Institut Fondamental d'Afrique Noire, Dakar, Senegal.

South African Jewish Museum. "New Exhibition: The Jews of District Six: Another Time, Another Place.” Press Release, October/November 2012 (Undated). South African Jewish Museum, Cape Town, South Africa.

\section{Interviews with Public Figures}

Alassane Ndaw, Philosopher and Former Colonial Soldier. February 15, 2013, Dakar.

Ben Diogaye Bèye, Filmmaker and Writer. April 29, 2013, Dakar.

Fazeela Haffejee, English Senior Curriculum Planner, Western Cape Education Department. November 13, 2012, Cape Town.

Mamadou Koné, Secretary General, Association sénégalaise des professeurs d'histoire et de géographie. 


\section{Interviews with Local Residents}

“El Haj Niang," Thiaroye Resident. March 6, 2013, Thiaroye.

"Issa Ndoye," Thiaroye Resident. March 17, 2013, Thiaroye.

"Margaret Hendricks" and "Carol Petersen," District Six Former Residents. November 1, 2012, Cape Town.

“Mrs. Mymoena Abrahams,” District Six Former Resident. November 19, 2012, District Six.

"Puah Gamsu," (Adult) Child of District Six Former Residents. December 22, 2012, Cape Town.

\section{Legislation}

Republic of South Africa. Promotion of National Unity and Reconciliation Act (No. 34 of 1995).

Republic of South Africa. National Heritage Resources Act (No. 25 of 1999). Union of South Africa. Population Registration Act (No. 30 of 1950). 